UII norden

BAT for lugtreduktion inden for levnedsmiddel- og fodervirksomheder 

III nordon 



\section{BAT for lugtreduktion inden for levnedsmiddel- og fodervirksomheder}

Karina Ødegård, Arne Oxbøl and Kasper Rovsing Olsen

TemaNord 2016:516 
BAT for lugtreduktion inden for levnedsmiddel- og fodervirksomheder Karina Ødegård, Arne Oxbøl and Kasper Rovsing Olsen

ISBN 978-92-893-4514-9 (PRINT)

ISBN 978-92-893-4516-3 (PDF)

ISBN 978-92-893-4515-6 (EPUB)

http://dx.doi.org/10.6027/TN2016-516

TemaNord 2016:516

ISSN 0908-6692

(C) Nordisk Ministerråd 2016

Layout: Hanne Lebech

Omslagsfoto: ImageSelect

Tryk: Rosendahls-Schultz Grafisk

Printed in Denmark

Denne rapport er udgivet med finansiel støtte fra Nordisk Ministerråd. Indholdet i rapporten afspejler dog ikke nødvendigvis Nordisk Ministerråds synspunkter, meninger, holdninger eller anbefalinger.

www.norden.org/nordpub

Det nordiske samarbejde

Det nordiske samarbejde er en af verdens mest omfattende regionale samarbejdsformer. Samarbejdet omfatter Danmark, Finland, Island, Norge og Sverige samt Færøerne, Grønland og Åland.

Det nordiske samarbejde er både politisk, økonomisk og kulturelt forankret, og er en vigtig medspiller i det europæiske og internationale samarbejde. Det nordiske fællesskab arbejder for et stærkt Norden i et stærkt Europa.

Det nordiske samarbejde ønsker at styrke nordiske og regionale interesser og værdier i en global omverden. Fælles værdier landene imellem er med til at styrke Nordens position som en af verdens mest innovative og konkurrencedygtige regioner.

\section{Nordisk Ministerråd}

Ved Stranden 18

1061 København K

Telefon (+45) 33960200

www.norden.org 


\section{Indhold}

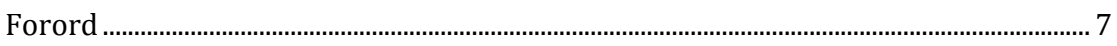

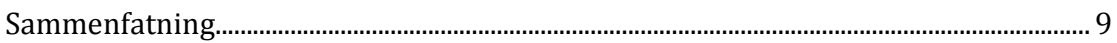

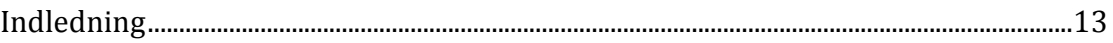

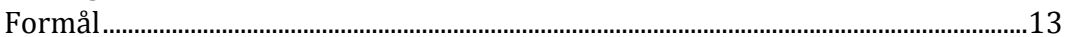

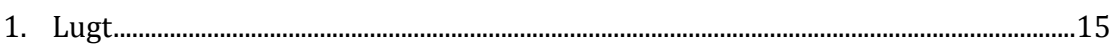

1.1 Hvordan opstår lugtgener ..............................................................................15

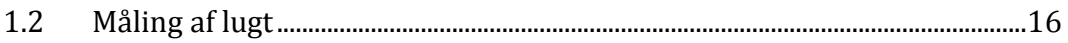

2. Teknologier for lugtrensning fra levnedsmiddelindustrier......................................19

$2.1 \quad$ BAT begrebet for lugt ....................................................................................19

2.2 Oversigt over teknologier.....................................................................................20

2.3 Procesændringer .........................................................................................21

$2.4 \quad$ Forbrænding (Oxidation i gasfase) ……........................................................22

$2.5 \quad$ Absorption i skrubber ......................................................................................26

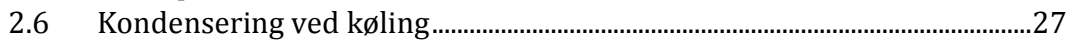

2.7 Biologisk rensning - biofilter og bioskrubber.................................................28

2.8 Adsorption på aktivt kul ...................................................................................30

$2.9 \quad$ Valg af forebyggelses- og renseteknologi ........................................................30

3. Lugtregulering i de nordiske lande.................................................................................33

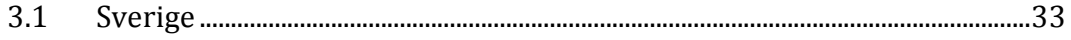

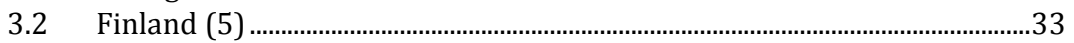

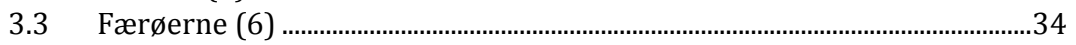

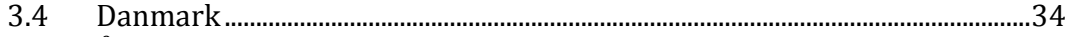

3.5 Åland.....................................................................................................................35

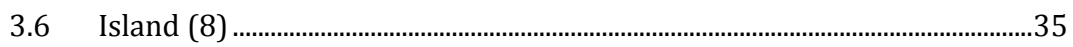

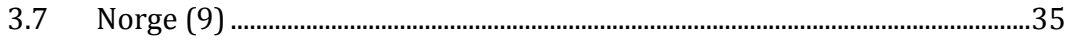

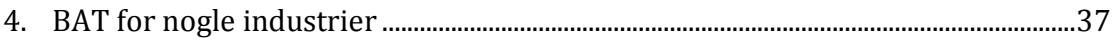

4.1 Destruktionsanstalter/kød- og benmelsfabrikker ..............................................40

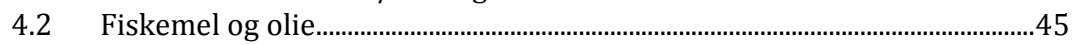

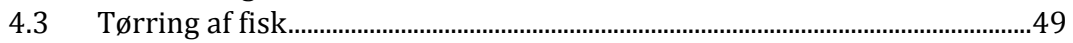

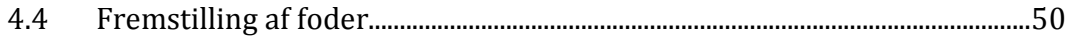

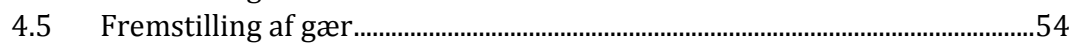

4.6 Lugtemission fra mejerier .................................................................................55

4.7 Beskrivelse af produktionen af ostepulver......................................................56

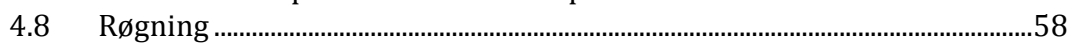

4.9 Farmaceutisk industri og fremstilling af kosttilskud ...................................61

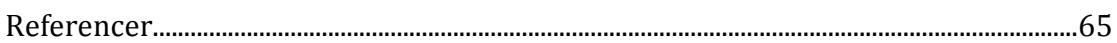

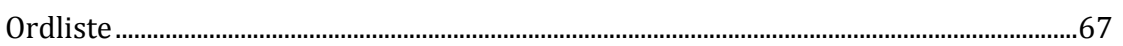

Sammenfatning engelsk ..................................................................................................69 



\section{Forord}

FORCE Technology og Molab AS har på opdrag af Nordisk Ministerråd udarbejdet denne rapport, som beskriver de teknologier til lugtreduktion, som benyttes inden for nogle brancher i Norden.

Der er i Norden forskellige retningslinjer for hvilke lugtniveauer, der bør være i omgivelserne af virksomhederne. Generelt er der ingen krav til etablering af lugtreduktionsanlæg, hvis niveauet kan opnås gennem fortynding via skorstene. Hvor skorstensløsning ikke er tilstrækkelig eller lokale forhold sætter grænser for højden, kan det dog være nødvendigt med etablering af lugtreducerende anlæg.

Som et første skridt $\mathrm{i}$ håndtering af lugt bør der undersøges muligheder for lugtreduktion ved procesændringer og generel håndtering. Det efterfølgende valg af metode til at opfylde krav til lugtpåvirkning af omgivelserne vurderes lokalt på baggrind af tekniske og økonomiske overvejelser.

I rapporten er resultaterne af disse overvejelse for nogle brancher i Norden beskrevet.

Projektet er finansieret af Nordisk Ministerråds arbejdsgrupppe for Holdbar Konsumtion og Produktion (HKP), vis undergruppe for BAT spørgsmål har styret projektet.

Følgende medlemmar i BAT-gruppen udgjorde styregruppen:

- Egil Strøm, Miljødirektoratet Norge.

- Kaj Forsius (Ordförande), Finlands miljöcentral SYKE Finland.

- Lena Ziskason, Umhvørvisstovan Færøyene.

- Sigurður Ingason, Umhverfisstofnun Island.

- Susanne Särs, Ålands miljö- och hälsoskyddsmyndighet Åland.

- Birgitte Holm Christensen, Miljøstyrelsen Danmark.

- Annika Månsson, Naturvårdsverket Sverige.

- Maria Enroth, Naturvårdsverket Sverige.

Februar 2016

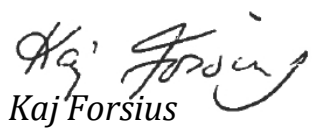

Ordførende for Nordisk BAT-gruppen,

Finlands Miljøcentral SYKE 



\section{Sammenfatning}

Overordnet er BAT for de beskrevne industriproduktioner, at:

- gennemføre lugtrisikovurdering og baseret på denne at gennemføre lugtreducerende tiltag

- indkapsle lugtgenererende processer og benytte afsug og undertryk for at styre luftstrømmen fra lugtstærke delprocesser

- benytte lukkede tanke eller containere for lugtstærke materialer, og begrænse lagringstiden til et minimum og køle ned, hvis det er nødvendig - ventilationsluft til lugtreduktion om nødvendig

- opretholde rene overlader i produktions- og lagerarealer

- tanke som indeholder væskebaseret affald sikres mod lækager og lukkes helt eller luftes for at reducere lugtafgivelsen

- fjerne lugtforbindelser fra varmebehandling ved udkondensering $\mathrm{i}$ kombination med varmegenvinding

- fjernelse af partikler og fedt fra ventilationsluft med egnede filtre. Dette kan også være nødvendig som forbehandling før brug af anden lugtreduktionsteknik

- genvinde opløsningsmidler i ventilationsluft eller brænde det af ved termisk oxidation.

For lugtrensing:

- Termisk oxidation /afbrænding.

- Kulfilter, gerne i kombination med ozonbehandling eller fotooxidation.

- Biofilter, gerne i kombination med egnet vådscrubber eller befugtning.

- Vådscrubber, gerne to-trins kemiske scrubbere.

- Bioscrubber. 
En del af den bedste tilgængelige teknologi i forhold til lugt er at reducere lugten så tæt på kilden som muligt. Så vidt muligt skal procesintegrerede teknikker benyttes. Herved minimeres unødige emissioner, og luftstrømmene, der emitterer lugt, begrænses. Det er dog kendetegnende for mange af de virksomheder, som kan give anledning til lugt, at de er etableret og udvidet i takt med behovet og mulighederne herfor. Det er derfor ofte vanskeligt at reducere lugt tæt på kilden, og løsninger, hvor luften behandles umiddelbart inden udledning til det fri (end of pipe), er derfor meget benyttet.

Generelt er der i forbindelse med reduktion af lugtpåvirkningen af omgivelserne stor fokus på økonomi. Det er derfor ofte en kombination af forskellige anvendelige teknikker, der giver den optimale løsning for den enkelte virksomhed. Denne kombination vil ofte være individuel, men de overordnede teknikker er de samme for den samme type produktion. For lugt er målet at undgå for høje koncentrationer i det område, som påvirkes af virksomheden. Dette kan gøres ved etablering af passende afkast eventuelt $i$ kombination med en eller anden form for reduktion af emissionen. Kombinationen vil desuden være afhængig af hvilken type produktion, der er tale om, hvor virksomheden er placeret og eventuelle lokale eller regionale begrænsninger. Et eksempel er brug af havvandsvaskere som lugtreducerende foranstaltning. Denne reduktionsmetode er velegnet til fjernelse af en række vandopløselige stoffer, blandt andet ammoniak og aminer, men har naturligvis sine begrænsninger. I nogle lande er det ikke acceptabelt at benytte havvandsvaskere af hensyn til recipienten. Det kan skyldes ringe vanddybde, lille vandgennemstrømning m.m. For andre virksomheder, som ikke er kystnære, er denne rensningsmetode ikke relevant.

Andre steder kan der være restriktioner i forhold til etablering af høje afkast, for eksempel på grund af en nærliggende lufthavn.

En forudsætning for, at den anvendte rensningsteknologi giver den $ø$ nskede virkning, er, at der foretages systematisk vedligehold og rengøring. Det skal ligeledes sikres, at anlæggenes funktionalitet og effektivitet efterprøves efter usædvanlige situationer såsom driftsforstyrrelser, høje temperaturer, bypass, særlige råvarer etc.

For nogle produktioner, hvor kvaliteten af råvarer er af betydning for lugten, er det vigtigt, at disse håndteres i lager- og transportsituationer, så der er mindst mulig udslip. Opbevaringen skal være forberedt til dette, og råvarerne bør ikke henstå unødigt længe. Opbevaring og transport af råvarerne, inden de kommer til virksomheden, hvor de bearbejdes, bør ske så hensigtsmæssigt som muligt eventuelt med køling, hvis der er mulighed herfor. På virksomhederne skal de opbevares i egnede rum med 
undertryk, så diffuse udslip minimeres. Luften, som suges fra rummet, bør eventuelt behandles, inden den ledes til et passende afkast.

Det særlige ved lugt er, at fortynding via forhøjelse af afkast kan give tilfredsstillende acceptable lugtforhold i omgivelserne. Denne løsning er accepteret i de nordiske lande.

Der er f.eks. i Danmark ikke krav til en maksimal lugtemission, men det angives, at lugtkoncentration i et afkast ikke bør overstige $100.000 \mathrm{LE} / \mathrm{m}^{3}$. 



\section{Indledning}

I et samfund, hvor industri og landbrug ligger tæt på beboelse og rekreative områder, er lugt blevet en væsentlig miljøparameter. I nogle lande har mange virksomheder derfor en grænseværdi for lugt i deres miljøgodkendelse og udledningstilladelser, som angiver, hvor meget den enkelt virksomhed må påvirke sine naboer med lugt. I andre lande er der i stedet nogle kvalitative beskrivelser af, at generende lugt ikke må forekomme. Under alle omstændigheder er der i mange virksomheder behov for at vide noget om, hvordan man kan bekæmpe eventuelle lugtende afkast og deraf følgende lugtgener i omgivelserne.

\section{Formål}

Projektet skal bidrage med information om, hvad den bedst mulige teknik (BAT) til bekæmpelse af lugt i nordiske levnedsmiddelvirksomheder er. BAT skal illustreres gennem dels beskrivelse af generelle rensningsteknogier og gennem udvalgte virksomheders valg af teknologi. Projektet skal illustrere muligheder og de betingelser, hvorunder valg er truffet, men giver ikke en fuldstændig beskrivelse af samtlige processer i levnedsmiddelindustrien.

Projektrapporten skal gavne både industrien og miljømyndighederne i de nordiske lande. Desuden skal rapporten være et bidrag fra de nordiske lande til BREF-opdateringen af FDM BREF-dokumentet. 



\section{Lugt}

Lugt opstår som følge af kemiske stoffers påvirkning af næsens lugtreceptorer og det derved udløste signal til hjernen, hvor signalet tolkes og bliver til en opfattelse af lugt. Gennem erfaring opbygger hjernen et "bibliotek" af mange - gode og dårlige - lugte, som sætter os i stand til at sige, hvad noget lugter af. Lugt er derfor en vigtig parameter i forbindelse med oplevelser, f.eks. gode mad- og drikkeoplevelser og nydelsen af f.eks. blomsterdufte. Lugt kan også give anledning til dårlige oplevelser, enten fordi lugten er dårlig eller forekommer i situationer, hvor den ikke er ønsket. Lugt kan også associeres til, om luften fra en virksomhed kan være farlig at indånde, og tjener således som et faresignal.

\subsection{Hvordan opstår lugtgener}

Nogle industrivirksomheder i de nordiske lande giver anledning til lugtende udslip. En række forhold gør, at det kan være meget forskelligt, om den lugt, der udsendes fra virksomheden, også giver anledning til lugt i omgivelserne, og om denne opleves som generende. I et samfund, hvor industrien ligger tæt på beboelse og rekreative områder, er risikoen for lugtgener blevet større, og lugt er derfor blevet en væsentlig miljøparameter. Industrien i de nordiske lande er meget varieret og forskellig fra land til land, både i forhold til produktion, virksomhedens størrelse og forhold såsom råvarer, driftsperioder, topografi og geografisk placering, der kan have stor indflydelse på hvorledes lugten opleves, og hvorledes omgivelserne påvirkes.

Lugtende stoffer opstår ofte i forbindelse med kemiske og biologiske processer og udgør som sådan en del af procesafkastet fra virksomheder, hvis ikke der foretages en rensningsproces, før det emitteres fra virksomheden.

Selv en omhyggelig rensning af et procesafkast forhindrer imidlertid ikke, at en virksomhed lugter, hvis et procesanlæg holdes dårligt vedlige, så der opstår utætheder hvorfra den lugtende procesgas strømmer ud til omgivelserne. Ligeledes kan procesgassen naturligvis strømme ud i forbindelse med tømning/fyldning af tankanlæg eller i forbindelse med reparation af fabrikationsanlæg. 
Lugtende stoffer opstår i mange forskellige sammenhænge. I nogle industrivirksomheder opstår de i forbindelse med behandling af naturprodukter, f.eks. destillation af olier eller ved syntese af kemiske forbindelser. Det drejer sig i sagens natur om en mangfoldighed af stoffer. I nogle industrivirksomheder hidrører lugte ofte fra mikrobiel nedbrydning af organiske forbindelser, f.eks. svovlbrinte og mercaptaner, men også kvælstofforbindelser i form af ammoniak, aminer og skatol kan give anledning til lugt.

De lugtdannende reaktioner sker ofte på steder, hvor de organiske stoffer opholder sig i beholdere, hvor luften ikke indeholder ilt, eller i iltfrit (anaerobt) vand, f.eks. kloaksystemer, brønde, klaringstanke og lignende. Håndtering af organisk materiale, herunder opvarmning og tørring, er processer, som i mange tilfælde kan give anledning til en lugtemission, som skal behandles, inden den ledes til det fri.

\subsection{Måling af lugt}

\subsubsection{Hvordan måles lugt?}

Lugtstoffer er flygtige, fortrinsvis organiske gasser, der selv i meget små koncentrationer kan opfattes af den menneskelige lugtesans. Lugt er i modsætning til andre forureninger, f.eks. $\mathrm{NO}_{\mathrm{x}}, \mathrm{SO}_{2}$ og støv i luften noget, de fleste mennesker med naturlig lugtesans selv kan registrere. Lugt er en subjektiv oplevelse. Det enkelte individ kan opleve samme lugt forskelligt i forskellige sammenhænge. Lugten af julekager er behagelig ved juletid, men kommer den fra en kagefabrik midt om sommeren, er det måske en knap så rar oplevelse. Endelig kan vores evne til at registrere lugten (vores lugttærskel) variere af mange årsager. Den klassiske er, at vi ikke kan lugte noget som helst, når vi er forkølede. Men også andre omstændigheder kan påvirke os.

Lugtmålinger tjener som baggrund for beregning af de lugtgener, naboer og omgivelser udsættes for. Det er derfor værdifuldt at få en talværdi for netop lugtoplevelsen til vurdering af størrelsen af lugtgenen. Det er i definitionen af denne talværdi uden betydning, om lugten fra et lugtstof er "god" eller "dårlig". 


\subsubsection{Lugtenheder}

Den størrelse, der bestemmes ved analysen er antallet af lugtenheder pr. $\mathrm{m}^{3}$ (på engelsk "odour units", ou $/ \mathrm{m}^{3}$ ). Den er defineret som den mængde af et lugtende stof eller en lugtende stofblanding, som fordelt i $1 \mathrm{~m}^{3} \mathrm{luft}$ netop kan lugtes af halvdelen af en gruppe mennesker, hvor den anden halvdel ikke kan lugte noget.

\subsubsection{Hvordan analyseres lugt?}

Der findes ikke velegnede, objektive, fysisk-kemiske målemetoder til måling af lugt, og bestemmelsen kan kun udføres ved brug af menneskers lugtopfattelse.

Det mest benyttede princip til bestemmelse af lugtkoncentrationer i de fleste europæiske lande samt i USA, Australien og New Zealand er at bestemme lugtstofkoncentrationen i luftprøver af et lugtpanel ved hjælp af et fortyndingssystem (olfaktometer), hvor lugtende luft og ren luft blandes i bestemte, kendte forhold, der doseres til paneldeltagerne. Formålet er at finde den fortynding af den lugtende luft, hvor paneldeltagerne netop kan erkende lugten.

På grundlag af de anvendte fortyndinger beregnes lugtkoncentrationen, idet der principielt kan sættes lighedstegn mellem antal fortyndinger og antal lugtenheder.

Baggrunden for bestemmelse ag lugtkoncentration er den europæiske standard EN 13.725 (1).

\subsubsection{Udtagning af prøver til analyse}

Prøvetagning er en væsentlig del af hele lugtanalysen. Det er selvfølgelig vigtigt, at prøven tages korrekt og behandles ordentligt frem til analysen gennemføres. Prøverne udtages i poser fremstillet af lugtfrit materiale, for eksempel Tedlar ${ }^{\circledR}$ eller Nalophan ${ }^{\circledR}$.

Prøverne udtages oftest med lungeprincippet, hvor der skabes et lille vakuum inde i prøvetagningsbeholderen. En tom prøvepose er anbragt inde i beholderen Prøveposen er direkte forbundet med en teflonslange til skorsten eller ventilationskanal, hvorfra prøven skal tages. Når vakuum i beholderen er stort nok, vil luft fra skorstenen/kanalen blive suget ind i posen for at udligne undertrykket. Metoden er let at anvende og giver ingen risiko for forurening af prøven.

Den udtagne prøve bringes til analyselaboratoriet hvor analysen fortages hurtigst muligt efter prøvetagning, dog maksimalt inden for 30 timer. 


\section{Hvilke industrier lugter}

En komplet oversigt over lugtende industri kan næppe udarbejdes, og der er en række industrier, som ikke findes i alle de nordiske lande. I flere lande er fiskeindustri væsentlig, mens det næsten ikke findes i andre. Papirindustri udgør også en væsentlig lugtkilde i flere af de nordiske lande, og det kan give anledning til særlige udfordringer. Nedennævnte eksempler på typer af anlæg, processer og aktiviteter giver erfaringsmæssigt ofte anledning til emission af lugtende stoffer og derfor mulighed for lugtgener:

- Destruktionsanstalter.

- Gærfabrikker, kafferisterier m.fl.

- Slagterier.

- Raffinaderier.

- Fiskemel og -oliefabrikker.

- Tørring af fisk.

- Foderfabrikker.

- Papir- og masseindustri.

- Sukkerfabrikker.

- Spildevandsrenseanlæg.

De generelle forhold omkring industriel lugt er dog alment gældende. Hvorvidt virksomheder giver anledning til generende lugt i omgivelserne, herunder særligt til naboer, er blandt andet afhængigt af virksomhedens drift, råvarer, placering, afkastforhold, lugtreduktionsanlæg, almindelig orden, rengøring og vedligehold. Det er vigtigt også at undgå lugt fra diffuse kilder, som kan komme fra lækager, åbne porte, døre eller vinduer eller spild på virksomhedens areal. 


\section{Teknologier for lugtrensning fra levnedsmiddelindustrier}

\subsection{BAT begrebet for lugt}

Den normale forståelse og anvendelse af BAT-begrebet er, at det er den bedst opnåelige teknologi til at reducere en udledning eller en belastning af omgivelserne fra en produktionsvirksomhed under hensyntagen til behov for rensning, muligheder og økonomi. Det er typisk udledning af kemiske stoffer og partikler, der skal reduceres af sundhedsmæssige hensyn.

Udledning af lugt og påvirkningen af omgivelserne er som hovedregel "kun" årsag til gener for de omkringboende mennesker, og der er normalt ikke tale om en sundhedsmæssig påvirkning, når man udsættes for en lugtgene. Dette skyldes, af de stoffer, der forårsager lugten, normalt findes i meget lave koncentrationer. Hvor lugtstoffer forekommer i så høj koncentration, at der kan være en sundhedsmæssig risiko, f.eks. hvis lugten skyldes formaldehyd eller svovlbrinte, vil disse stoffer normalt blive reguleret direkte med grænseværdier for stofferne.

En vurdering af hvilke teknologier, der er BAT til reduktion af lugt fra forskellige typer virksomheder, har derfor en ekstra dimension, fordi det ikke nødvendigvis er den samlede udledning af lugt, der skal reduceres, men mere koncentrationen i eller påvirkningen af omgivelserne der skal ned på et acceptabelt niveau. Derfor kan høje afkast, som giver bedre spredning og lavere koncentrationer i omgivelserne, også være BAT for lugt, fordi det ofte er den billigste og mindst miljøbelastende måde at reducere påvirkningen af omgivelserne.

I mange sammenhænge er en kombination af rensning og høje afkast, hvor noget af lugtemissionen reduceres, at betragte som BAT. Det gælder f.eks. hvor en stor lugtemission i en lille volumenstrøm kan være let at reducere. I en stor volumenstrøm med lav lugtkoncentration kan det være anderledes bekosteligt. Atmosfæren har en betydelig kapacitet til nedbrydning af organiske forbindelser, herunder lugtstoffer, ved fotooxidation, så hvis udledningen af lugtstoffer sker uden gene for de omkringboende, er der måske ingen miljømæssig påvirkning, som berettiger rensning frem for spredning med høje afkast. Der kan dog være lokale forhold, 
som betinger en bedre rensning, f.eks. i nærheden af følsomme naturområder, eller hvor der af hensyn til områdets herlighedsværdi ikke må etableres høje afkast.

\subsection{Oversigt over teknologier}

Teknologier til rensning og reduktion af lugtemission er generelt de samme, som anvendes til rensning for alle mulige andre emissioner af både organiske og uorganiske stoffer, der findes på dampform. Lugtemissioner er primært associeret til stoffer på dampform, som ved vejrtrækningen uvilkårligt kommer i kontakt med næsens lugtceller. Partikler kan dog i nogle tilfælde også medvirke til lugtemission, hvis lugtstoffer er adsorberet til partiklerne og efterfølgende frigøres, når de spredes i atmosfæren og/eller når næsens lugtceller.

De teknologier, der tages i anvendelse, har som det primære formål at reducere påvirkningen i omgivelserne.

Der er tre principielt forskellige strategier at følge:

- Procesændringer, som reducerer emissionen af lugtstoffer

- Rensning, som tilbageholder allerede dannede lugtstoffer

- Oxidation (forbrænding)

- Oxidation med radikaler - UV/ozon/plasma

- Absorption i skrubber - $\mathrm{pH}$ regulering og evt. oxiderende kemikalier

- Kondensering ved køling - ofte i forbindelse med en skrubber

- Biologisk rensning - biofilter og bioskrubber

- Adsorption - aktivt kul

- Fortynding af lugtstofferne til acceptable niveauer i omgivelserne

- Spredning - høje afkast/skorstene

Kombinationer af alle strategier/metoder kan anvendes.

Alle end of pipe teknologier (dvs. rensning eller spredning) giver i princippet kun udgifter og ekstra arbejde for virksomheden. I nogle tilfælde kan der ske en vis udnyttelse af spildvarme, men det er aldrig nok til at give en positiv driftsøkonomi. Det er derfor altid vigtigt at vælge den optimale renseteknologi i forhold til parametrene: god rensning, driftssikkerhed, driftsomkostninger. Driftsomkostninger og investeringer må 
ikke undervurderes, men det er vigtigt ikke at bygge for små rensningsanlæg i bestræbelserne på at spare og undgå priskonkurrence.

Det er således også vigtigt at tænke på evt. kommende udvidelser, så et anlæg med tilstrækkelig kapacitet ikke bliver for lille. En for stort anlæg vil oftest virke tilfredsstillende, samtidig med at der er potentiale for udvidelser.

\subsection{Procesændringer}

Forebyggelse af lugtemission ved at foretage procesændringer kan mindske behovet for efterfølgende rensning.

Det er vigtigt at være opmærksom på hvilke kilder, der er til lugtafgivelse fra processen. En række forhold kan have en indflydelse, herunder:

- Råvarekvalitet.

- Lagringstid.

- Temperatur.

- Fugtighed.

- Rengøring.

- Vedligehold.

- Indkapsling af procesanlæg.

Disse punkter er væsentlige sammen med en generel fokus på optimering og substitution med potentielt mindre lugtende stoffer, hvor det er teknisk og økonomisk forsvarligt.

I nogle tilfælde kan recirkulering af procesventilationsluft eventuelt efter køling og kondensering give anledning til reduktion af den lugt og luftmængde, der efterfølgende skal behandles, men det er afhængigt af hvorvidt det er teknisk og økonomisk acceptabelt.

Generelt er det en fordel at minimere den luftstrøm, som skal behandles i reduktionsanlæg. Det reducerer omkostninger ved såvel anskaffelse som drift. 


\subsection{Forbrænding (Oxidation i gasfase)}

Brændbare lugtstoffer kan effektivt fjernes fra gasstrømme ved forbrænding, som ofte betegnes oxidation. Det er normalt den ultimativt mest effektive rensemetode, fordi der normalt kan opnås meget høj og effektivt rensning, dvs. 90-99,9\%.

Oxidation er en kemisk proces, som nedbryder kemiske stoffer enten fuldstændigt til kuldioxid og vand eller delvist til andre kemiske stoffer. Hvis man vælger at anvende oxidation til reduktion af lugtstoffer, er det vigtigt at danne sig et overblik over, hvad der sker ved processen. Det nytter f.eks. ikke at reducere visse lugtstoffer, hvis der ved processen blot dannes andre - evt. stærkere lugtende stoffer.

\subsubsection{Termisk og katalytisk forbrænding}

Såvel termisk som katalytisk oxidation er særdeles effektive teknologier, som kan fjerne brændbare forureningskomponenter som for eksempel kulbrinter fuldstændigt fra procesgasser (forbrænding). Forbrænding er ofte en attraktiv løsning på et forureningsproblem, fordi de fleste organiske og en del uorganiske forbindelser derved oxideres til mindre skadelige eller mindre lugtende forbindelser.

Den termiske oxidation af forureningskomponenter sker ved høj temperatur $\left(700-1.000^{\circ} \mathrm{C}\right)$, mens den katalytisk oxidation sker ved lavere temperatur $\left(300-400^{\circ} \mathrm{C}\right)$ under anvendelse af en katalysator.

Da det er det muligt at opnå en høj rensningsgrad såvel ved termisk som ved katalytisk oxidation, er de lokale procesforhold (herunder økonomi og driftssikkerhed) afgørende for valget mellem de to processer. Generelt vil lave forureningskoncentrationer kalde på katalytisk oxidation, mens termisk oxidation er fordelagtigt ved høje forureningskoncentrationer.

\section{Fordelene ved forbrænding er bl.a.}

- Der kan opnås meget høje rensningsgrader (> $99 \%$ ).

- Anlægget er ikke følsomt for moderate ændringer i volumenstrømmen eller forureningskoncentration.

- Rensningsgraden afhænger i mindre grad af hvilke forureningskomponenter, der er tale om.

- Ved termisk forbrænding er der ingen ændringer i rensningsgraden med driftstiden.

- Der er mulighed for at kombinere med varmegenvinding. 


\section{Ulemperne er bl.a.}

- Store investerings- og driftsudgifter.

- Der kan opstå andre forureningsproblemer, hvis afkastluften indeholder andet end $\mathrm{C}, \mathrm{H}$ og $\mathrm{O}$.

- Et indhold af $\mathrm{S}$ og $\mathrm{Cl}$ vil give anledning til $\mathrm{SO}_{2}$ - og $\mathrm{HCl}$-dannelse.

- $\mathrm{NH}_{3}$ og aminer giver anledning til $\mathrm{NO}_{\mathrm{X}}$ dannelse.

- Ved katalytisk forbrænding kan der ske forgiftning af katalysatoren eller tilstopning med partikler

- Forudsætter eller favoriserer en kontinuert proces grundet høje omkostninger ved opstart.

\subsubsection{Oxidation med radikaler - UV/ozon/plasma}

Der er udviklet forskellige teknologier, der anvender kold oxidation med ozon og radikaler til at nedbryde lugtstoffer ved oxidering til mindre lugtende stoffer. De anvender forskellige metoder til at producere ozon og/eller andre radikaler. Teknologierne er:

- Plasma, hvor der i et spændingsfelt producerer radikaler ud fra luftens indhold af $\mathrm{O}_{2}, \mathrm{~N}_{2}$ og vand.

- UV-C lamper, som producerer ozon og $\mathrm{OH}$-radikaler ud fra luftens $\mathrm{O}_{2}$ og vand.

- Ren ozon der produceres i en lille luftstrøm gennem en ozon generator, hvorefter det blæses ind i kanalen med luften, der skal rense.

Fælles for teknologierne er, at radikalerne reagere med alle organiske stoffer, og ikke kun lugtende organiske stoffer, så hvis koncentrationen af organisk stof varierer, så kan reduktionen af lugt variere tilsvarende, så høj koncentration af organisk stof giver lavere lugtreduktion.

Der er også stor forskel på den oxiderende effekt af ozon og radikaler, og hvor hurtigt de reagerer med forskellige stoffer, og hvilke stoffer og bindinger de kan reagere med. F.eks. regnes ozon for at være et af de kraftigste oxidationsmidler, men det betyder ikke, at det hurtigt kan nedbryde alle stoffer. Tværtimod så kan ozon ikke oxidere alle mulige stoffer, og desuden er reaktionstiden relativ lang for mange af de stoffer, det kan oxidere, og med de mængder af ozon der normalt doseres med denne type rensning, så vil en effektiv rensning ofte være urealistisk. OH-radikaler er langt mere effektive end ozon, idet de reagerer langt hurtigere og mere effektivt. 
Der er flere forhold, man skal være meget opmærksom på ved anvendelse af ozonanlæg til lugtreduktion. Det største problem er, at den tilsatte ozon normalt ikke når at reagere fuldstændigt, inden udledning til luften, så der er en målelig ozonkoncentration i afkastet.

Ved prøvetagning til lugtbestemmelse eller vurdering af lugten, vil restozonen kunne maskere lugten, så man tror, at den oprindelige lugt er fuldstændig væk, men efter fortynding med udeluft svarende til spredningen fra afkastet, kan den oprindelige lugt komme frem igen. Dette gør det meget vanskeligt at vurdere ozonbehandlingens effekt på stedet, og det giver også nogle problemer i forhold til at bestemme lugtkoncentrationen. Hvis lugtmålingerne bare udføres efter den normale procedure, så vil restindholdet kunne nå at reagere med lugtstofferne i posen, og dermed reducere lugtkoncentrationen i løbet af de op mod 30 timer, der må gå fra prøvetagning til lugtbestemmelse. Da ozon også lugter, vil restozon også kunne bidrage til lugtkoncentrationen i prøven. Hvis der er restozon, bør det fjernes ved opsamling af prøve til lugtbestemmelse, f.eks. i en denuder.

\section{Plasma}

Plasma (som egentlig er ikke-termisk plasma) er en lugtreduktionsteknik baseret på at skabe en høj-reaktiv zone i gassen, hvor lugtstoffer nedbrydes.

Plasmatilstanden skabes ved, at gassen ledes gennem et reaktionskammer bestående af et antal sekskantede metalkanaler, hvor der i midten af hver er monteret en tynd wire der påføres en høj spænding (optil $40 \mathrm{kV}$ ), som genererer et spændingsfelt (corona) i kanalen, hvilket genererer plasmatilstanden, hvor frie elektroner, ioner og radikale sameksisterer.

Radikalerne i plasmaet reagerer med organiske stoffer, herunder lugtstoffer, der ved oxidering nedbrydes til mindre lugtende stoffer. De mest aktive radikaler i denne proces er nitrogen-, oxygen- og hydroxylbaserede radikaler, som dannes ud fra luftens indhold af nitrogen, oxygen og vand.

FDM BREF angiver, at plasma kan reducere lugtemissionen med 75-96 \%, afhængigt af procesforholdene og lugtkarakteren, samt at teknologien er installeret på mindst 13 anlæg, primært i fiskeindustrien.

FORCE Technology har erfaringer fra en del af disse anlæg, som viser en meget varierende lugtrensende effektivitet, så disse anlæg kan ikke, eller kun ved nogle målinger leve op til de angive 75-96 \% reduktion. Årsagen kan være, at der dannes varierende mængder af radikaler, og at også ikke lugtende organiske stoffer kan reagere med radikalerne, og med en sandsynlig variation i indholdet af organiske stoffer og lugtkoncentration i den luft, der skal renses, varierer lugtreduktionen. På grund af denne usikker- 
hed, mener vi ikke at plasma generelt kan betegnes som BAT for lugtrensning, fordi det tilsyneladende ikke fungerer effektivt på alle anlæg og under alle driftsforhold. Anvendelse af plasma teknologien bør derfor kun ske efter grundige test, som dels viser effekten under forskellige driftsforhold og højest mulig koncentration af organisk stof i luften, og dels er udført med målinger af lugtkoncentration, hvor en eventuel maskerende effekt fra bl.a. resterende ozon og NOx er fjernet fra prøverne.

\subsubsection{Ozon genereret med UV-C lamper}

UV-C lamper til generering af ozon er ofte UV-C lamper (rør), der har lys i de bølgelængder, der producerer ozon og afledte radikaler, f.eks. $\mathrm{OH}-$, ud fra luftens $\mathrm{O}_{2}$ og vandindhold. UV-C lyset kan også medvirke til en direkte nedbrydning af visse forbindelser, og derudover har de en stor mikroorganismedræbende virkning. Da OH-radikaler er langt mere effektive end ozon, er det en fordel med et højt indhold af vand i den luftstrøm der behandles, da vand er nødvendigt for dannelsen.

UV-C lamperne monteres typisk i firkantede kasser, hvor luften ledes igennem, og der skal angiveligt være en opholdstid i anlægget, så reaktionerne kan nå at forløbe, inden luften ledes ud gennem afkastet.

Der findes ikke ret mange tilgængelige data om den opnåelige lugtreduktion med UV-C behandling. Leverandører af den slags anlæg lover typisk op til 95-99 \% lugtreduktion, men FORCE Technology har ikke kendskab til dokumentation for så høj effektivitet, men vi har kendskab til dokumenterede målinger af lugtreduktioner på omkring 50 \% i køkkenudsugninger.

\subsubsection{Ozon genereret med corona (elektriske udladninger)}

Når det lyner, dannes der ozon, hvilket giver den karakteristiske lugt af tordenvejr. Den proces kan efterlignes ved elektriske udladninger mellem to elektroder. Ved denne proces produceres ozon i en lille luftstrøm (eller en strøm af ren $\mathrm{O}_{2}$ ), som blæses ind i den luftstrøm, der skal behandles.

Her skal der naturligvis også være en passende opholdstid, så ozonen kan nå at reagere med lugtstofferne.

Ved corona processen kan der også dannes $\mathrm{NO}$ og $\mathrm{NO}_{2}$ fra luftens $\mathrm{N}_{2}$, men mængden kan muligvis minimeres ved valg af coronarør og den anvendte højspænding.

Der findes ikke tilgængelige dokumenterede data om den opnåelige lugtreduktion med ozon behandling. Leverandører af den slags anlæg lover typisk op til 95-99 \% lugtreduktion, men FORCE Technology har ikke 
kendskab til nogen målinger der dokumenterer en sådan lugtreduktion. Til gengæld har vi kendskab til målinger på testanlæg, hvor der stort set ikke var nogen lugtreducerende effekt.

\subsection{Absorption i skrubber}

Vandopløselige kemiske stoffer, herunder lugtstoffer kan fjernes fra luften ved adsorption og eventuelt kemisk reaktion i væske. Der anvendes oftest vand og tilsætning af ét eller flere kemikalier, til at øge opløsning af stofferne i væsken. Absorption er en overførsel fra luft til væske, og absorptionens effektivitet afhænger af ligevægtsforholdene mellem luft og væske. Efter en vis tid opstår ligevægt mellem luft og væske, hvorefter der ikke sker yderligere rensning. Det er derfor oftest nødvendigt at forskyde ligevægten mod væsken.

Hvis lugtstofferne er basiske eller sure, kan de let tilbageholdes effektivt $i$ en sur hhv. basisk væske, og det opnås let ved at pH-regulere væsken med syre eller base. Neutrale stoffer har normalt en begrænset opløselighed i vand, men hvis de kan reagere kemisk, f.eks. ved oxidation i væsken, og til en mere vandopløselig form, kan absorptionskapaciteten øges.

Det er derfor vigtigt at få et overblik over de vigtigste lugtstoffer, der skal fjernes, for at kunne vælge de mest optimale kemikalier til at forbedre absorptionen.

Selvom ligevægten forskydes effektivt mod væsken, er der altid et behov for tilførsel af frisk væske, så koncentrationen ikke stiger hele tiden.

Det er muligt at opnå en høj rensningsgrad ved absorption især ved kemisk absorption. Det er en robust og velgennemprøvet teknologi, som finder mange anvendelser. Det er muligt at opnå 90-95 \% rensning med kemiske absorptionsenheder, og det er således ikke helt så effektivt som termisk oxidation (op til $99 \%$ ). Som regel vil høje forureningskoncentrationer samt høje volumenstrømme favorisere kemisk absorption i forhold til katalytisk eller termisk oxidation.

\section{Fordele ved at anvende absorption og kemisk reaktion i væske er}

- Der kan opnås høje rensningsgrader.

- Anlægget er ikke følsomt for ændringer i forureningskoncentrationen.

- Rensningsgraden afhænger kun i mindre grad af hvilke forureningskomponenter, der er tale om, hvis enheden designes rigtigt.

- Der ingen ændringer i rensningsgraden med driftstiden - når væsken skiftes løbende. 


\section{Ulemper ved at anvende absorption er}

- Store driftsudgifter til vand, energi og kemikalier.

- Der kan opstå andre forureningsproblemer som eksempelvis klorerede forbindelser.

- Der kan forekomme uønsket sammensat spildevand, der skal ledes til spildevandsrensning.

\subsection{Kondensering ved køling}

Procesluft med højt vandindhold og indhold af vandopløselige lugtstoffer kan med fordel køles således, at noget af vandet og de vandopløselige lugtstoffer kondenserer. Vandopløselige lugtstoffer forekommer i mange levnedsmiddelindustrier, som anvender biologiske råvarer med et højt indhold af vand, og de potentielle lugtstoffer er ofte vandopløselige, f.eks. i fremstilling af foder og mælkeprodukter.

Kondensation ved køling er særligt fordelagtig i tørreprocesser, hvor vandindholdet i procesluften er høj og har en forholdsvis høj temperatur. Køling kan opnås ved luftkøling i en høj skorsten eller ved anvendelse af varmevekslere, der køles med luft eller med vand, som f.eks. køles med luft eller via et køletårn. Køling fra høje temperaturer kan gøres økonomisk fordelagtigt, og ved kondensering af store mængder vand, kan der opløses betydelige mængder lugtstoffer, i nogle tilfælde helt op til $50 \%$. Ved aftagende mængder vand og lavere temperatur aftager effekten af en køling. Det er dog en betydelig fordel, at processen ikke indebærer brug af kemikalier, og kondenserede vand med lugtstofferne kan typisk ledes direkte til biologisk rensningsanlæg, hvor lugtstofferne normalt er let omsættelige.

Køling kan være en nødvendig proces, hvor den primære rensning af luften skal ske ved adsorption i f.eks. et kulfilter. Hvis ikke luften køles, kan kondenseret vand ødelægge effektiviteten af absorptionen. En evt. reduktion ved kølingen er således en sidegevinst.

Køling anvendes ofte som en forrensning eller som integreret del af den egentlige rensning i en skrubber, hvor lavere temperatur normalt giver bedre rensning. Anvendes kemikalier i skrubberen, f.eks. til pH regulering, så kan der spares en del kemikalieudgift, hvis en del af de sure eller basiske stoffer kan fjerne ved en forudgående kondensering. 


\subsection{Biologisk rensning - biofilter og bioskrubber}

Biologisk luftrensning anvender samme princip, som er kendt fra biologisk spildevandsrensning, idet luftens indhold af forureningskomponenter herunder lugtstoffer nedbrydes af mikroorganismer, enten til mindre molekyler eller helt til kuldioxid og vand. Hvor formålet er reduktion af lugtemission, er det vigtigt at sikre sig, at lugtstofferne ikke nedbrydes til andre lugtstoffer.

Der anvendes to forskellige principper for biologisk luftrensning:

- Biologiske skrubbere.

- Biologiske filtre.

\subsubsection{Biologiske skrubbere}

I en biologisk skrubber findes mikroorganismerne typisk både i en vandfase og som en biofilm på et bæremateriale, som væsken risler ned over, mens luften, der skal renses, ledes op igennem bærematerialet. Den biologiske skrubber har derfor stor lighed med et absorptionstårn (se afsnit 2.5), idet det er en forudsætning, at lugtstofferne effektivt kan overføres fra luften til væsken. Bakterierne omsætter lugtstofferne, som er absorberet i vandet, og holder derved koncentrationen lav, så absorptionen kan være effektiv. I en kemisk skrubber er det en kemisk reaktion, der binder eller omdanner lugtstofferne.

For at nedbrydningen kan foregå optimalt er det vigtigt, at temperaturen er på et niveau, hvor betingelserne for mikroorganismernes vækst og omsætning er bedst mulig, ligesom det skal sikres at de har den nødvendige tilførsel af næringssalte ( $\mathrm{N}$ og P), samt visse sporstoffer.

Mikroorganismerne som sørger for omdannelsen er mere følsomme over for store variationer i driftsforholdene end en kemiske skrubber, og en biologisk skrubber er derfor afhængig af en forholdsvis ensartet sammensætning og koncentration af lugtstofferne, ligesom temperaturen skal holdes nogenlunde konstant. Der vil dog normalt være en relativt stor mængde vand i en biologisk skrubber, som giver en vist robusthed over for variationer i luftens koncentration og temperatur.

\section{Blandt fordelene er}

- Relativt lave investerings- og driftsomkostninger.

- Begrænset brug af kemikalier.

- Spildevand, som kan ledes til f.eks. kommunalt rensningsanlæg. 


\section{Ulemperne er f.eks.}

- Eventuelle problemer med varierende procesdrift og deraf følgende varierende koncentrationer i luften.

- Følsom over for driftsforstyrrelser.

- Øvre temperaturgrænse af indgående luft bør ikke overstige $50{ }^{\circ} \mathrm{C}$.

Metoden er mest anvendelig til luftforureninger i relative lave koncentrationer.

\subsubsection{Biologiske filtre}

I et biologisk filter sker der principielt de samme processer som i en biologisk skrubber, men de aktive organismer sidder på et fugtigt, fast, organisk materiale, som kan være spagnum, kompost, neddelt træ (flis), men i de senere år anvendes i stigende grad uorganiske bærematerialer, f.eks. Leca nødder, som holder betydeligt længere fordi det ikke nedbrydes som de organiske gør. Luften ledes gennem bærematerialet og organiske stoffer, herunder lugtstoffer adsorberer hertil, hvorefter organismerne omsætter dem. Mikroorganismerne kan udvikles fra luftens naturlige indhold af bakterie og svampesporer, men nogle leverandører af biologiske filtre foretager en målrettet podning af det biologiske filter, før det tages i brug. Derved sikres en optimal omsætning af de aktuelle lugtstoffer.

Der kan ske en relativt høj omsætning af lugtstoffer (op til $90 \%$ ), og metoden anvendes især til at fjerne lugtstoffer, som forekommer i relativt lave koncentrationer, og som let kan adsorbere til filtermaterialet.

Udover ensartet tilførsel af lugtstoffer, skal fugtigheden være relativt $h ø j$. Biomassen bør derfor være relativt porøs, således at den kan holde på fugtigheden og bevare sin adsorptionsevne. Surhedsgraden skal også svare til organismernes optimale forhold, og pH skal derfor justeres efter behov.

Hvis man anvender organiske bærematerialer, kan der ske en naturlig omsætning af bærematerialet, som derved mister sin bæreevne. Hvis biofilteret derfor falder sammen, dannes der lukkede områder i filteret med stort tryktab og områder, hvor procesgassen passerer med en meget stor hastighed. Effekten er, at det aktive område reduceres, og kontakttiden bliver for kort, når hastigheden øges. Sådanne filtre skal derfor vedligeholdes, og bærematerialet byttes ud efter en vis tid. Problemet kan forebygges ved at anvende et uorganisk bæremateriale, f.eks. Leca nødder, som dog også skal skiftes efter en årrækkes drift, men så er årsagen stigende tryktab pga. tilstopning af bakterievækst og/eller partikler. 
Biofiltrer anvendes typisk ved store luftmængder med moderate forureningskoncentrationer.

\subsection{Adsorption på aktivt kul}

Aktivt kul er meget effektivt til at adsorbere organiske lugtstoffer, og da lugtstoffer fra fødevare- og foderstof-virksomheder meget hyppigt er organiske stoffer, så er den potentielle lugtreducerende effekt meget stor. Adsorptionsevnen afhænger dog af mange faktorer, herunder stoffernes fysiske og kemiske egenskaber, koncentration, temperatur og luftfugtighed.

Effektiviteten reduceres med stigende temperatur og luftfugtighed, så temperaturen bør være under ca. $40{ }^{\circ} \mathrm{C}$ og den relative luftfugtighed (RF) mindre end 60-80\%, for at opnå optimal rensning.

Ved anvendelse af kulfilter er det vigtigt at undgå en stor belastning med partikler, fordi det hurtigt kan tilstoppe kulfilteret. Det bør derfor altid afklares, om der bør være filtrering af luften før kulfilteret, for at opnå optimal drift og levetid.

Aktivt kul vil adsorbere næsten alle organiske stoffer, og da kullene har en begrænset adsorptionskapacitet, som er i størrelse nogle \% og op til 20-30 \% afhængigt af stoffernes egenskaber og koncentration, så det er vigtigt at kende indholdet af organiske stoffer, eventuelt lave test af kullenes adsorptionskapacitet for at kunne beregne levetiden og dermed driftsomkostningerne for et kulfilter.

Rensning for lugt med aktivt kul er mest velegnet til små koncentrationer og relativt begrænsede luftmængder. Det kan også anvendes til store luftmængder, men så bør koncentrationen af lugt og andre VOC være meget lav, for ellers kan forbruget af kul og dermed hyppigheden for udskiftning af kullene blive meget omkostningskrævende.

Opnåelig rensning med aktivt kul er typisk 90-99,9\%.

\subsection{Valg af forebyggelses- og renseteknologi}

I FDM BREF (11) er angivet en tabel der summerer generelle kriterier for valg af renseteknologi for lugt og VOC. Denne tabel er her gengivet i revideret form, som bl.a. medtager UV-C og ozon-behandling sammen med plasma under kold oxidation, og biologisk rensning er delt op i biofiltre og bioskrubbere. Desuden er scoringen revideret lidt, med fokus på rensning for lugt. 
Bemærk, at tabellen kun omhandler teknologiernes driftsmæssige anvendelighed i forhold til de angive konditioner i luften, og slet ikke forholder sig til om teknologien er anvendelig eller hvilken rensningseffektivitet der kan opnås. En lav score betyder derfor ikke at teknologien ikke kan anvendes, men at det kan være nødvendigt med en forbehandling, f.eks. i form af en køling eller en rensning for partikler.

Tabel 1: Kriterier for anvendelighed af renseteknologier for lugt

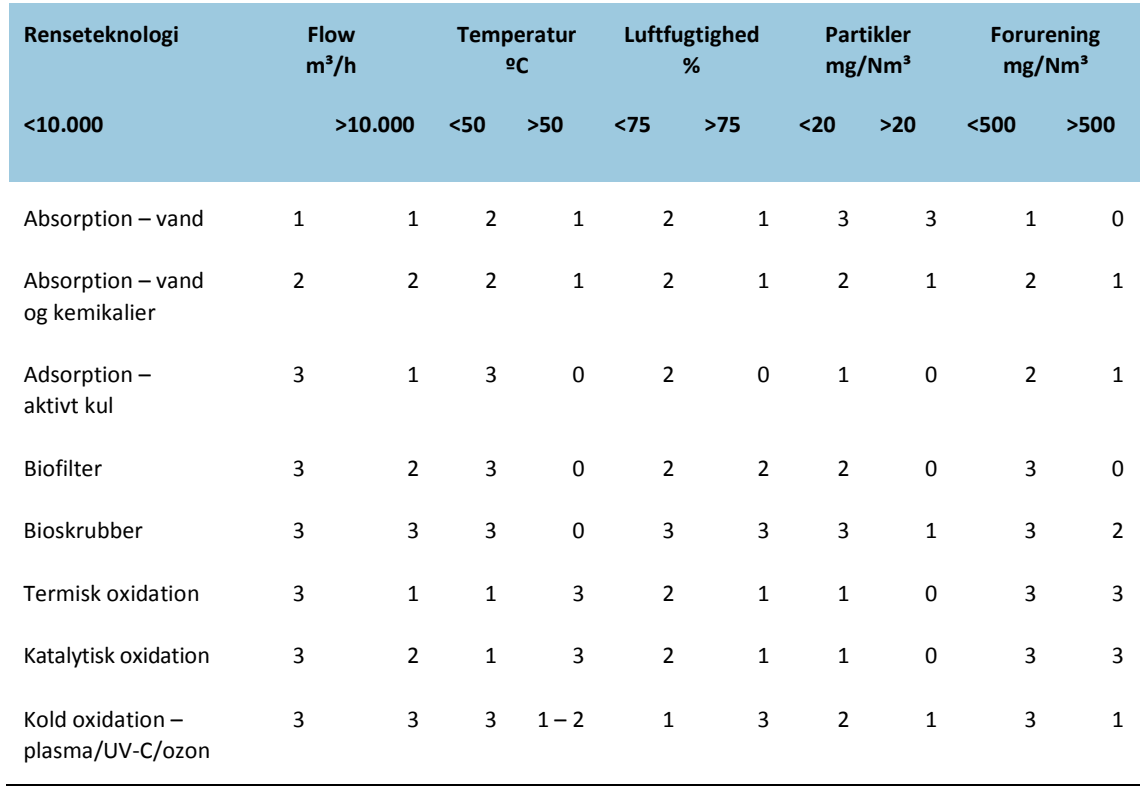

Note: $\quad$ 0: Denne teknologi er ikke anvendelig eller vil højest sandsynligt ikke være effektiv ved den givne kondition.

1: Bør overvejes, men er sandsynligvis ikke den bedste teknologi til den give kondition.

2: Meget anvendelig teknologi ved de givne konditioner.

3: Optimale konditioner og driftsbetingelse for den givne renseteknologi. 



\section{Lugtregulering $\mathbf{i}$ de nordiske lande}

Der er meget varierende tilgange til lugtregulering i de nordiske lande. Nedenfor gives et kort resumé af oplysninger fra myndighedspersoner og rådgivere i de forskellige lande.

\section{$3.1 \quad$ Sverige}

Svensk miljøregulering omtaler ikke lugt meget (1) og der er ingen direkte grænseværdier for lugt i eksternt miljø (dvs. hos naboer til virksomheder) (3). Lugtproblemer betragtes dog alligevel som en vigtig opgave for tilsynsmyndighederne, og alle virksomheder nær boligområder kan få lugtkrav. Disse stilles dog ofte som krav til enkeltforbindelser, som forårsager lugten (1). I udslipstilladelser formuleres det f.eks., at hvis lugtgener opstår som følge af virksomhedens aktivitet, skal virksomheden i samarbejde med tilsynsmyndigheden finde tiltag til at begrænse generne.

Myndighedernes fokus er på klagefrekvensen således, at mange klager giver strengere krav, Erfaringer fra 1970'erne viser, at klager over lugt forekommer hvis lugttærsklen overskrides en eller et par procent af tiden. Det medførte, at i 1980'erne og 1990'erne blev der gennemført et stort antal frekvensspredningsberegninger for at sammenligne med $1 \%$ niveauet (4).

I erhvervsvirksomheder skal bedst mulige teknik anvendes for at forebygge gener. Bedst mulige teknik kan f.eks. være håndtering af afkastluften eller passende afstand fra virksomhed til naboer (3).

\subsection{Finland (5)}

Finland har ikke en grænseværdi for lugt i omgivelserne, men hvor lugt stammer fra svovlforbindelser, anvendes en grænseværdi for koncentrationen af total svovl på $10 \mathrm{ug}(\mathrm{S}) / \mathrm{m}^{3}(20 \stackrel{\circ}{\circ}, 101,3 \mathrm{kPa})$. Den næsthøjeste 24 timers middelværdi skal overholde grænseværdien. Grænseværdien 
er fastsat af sundhedshensyn og forhindrer ikke lugtgener. Det er i Finland forbudt at "formindske den generelle herlighedsværdi af miljøet", men der er ikke fastsat officielle retningslinjer for lugtpåvirkning. Finske myndigheder bruger ofte "lugtretningslinjer", som er baseret på vurderinger udført af VTT Technical Research Centre i Finland. Vurderingen lægger op til, at generende lugtfrekvens kan være 3-9\% af den samlede tid og, at andelen af tydeligt generede personer kan være $25-50 \%$. Hvilke procentsatser, der fastsættes i aktuelle tilfælde kan afhænge af lugtens hedoniske karakter (behagelig eller ubehagelig), idet ubehagelig lugt forårsager gener ved lavere lugtfrekvens.

Der er således ikke en eksakt retningslinje for lugt. I Miljøtilladelser kan der være begrænsninger for lugtende emission (f.eks. for komposteringsanlæg). Det kan være en grænseværdi for lugtkoncentration på f.eks. $5.000 \mathrm{OU}_{\mathrm{E}} / \mathrm{m}^{3} \mathrm{i}$ udgående gas eller en grænseværdi for kildestyrken på f.eks. $2.000 \mathrm{OU}_{\mathrm{E}} / \mathrm{s}$.

Lugtenheder skal måles i henhold til EN 13.725. Ved feltundersøgelser anvendes primært VDI's retningslinjer. Miljømyndighederne kan acceptere eller afvise den foreslåede målemetode.

\subsection{Færøerne (6)}

På Færøerne stilles der krav til lugt i miljøgodkendelsen for hver enkelt virksomhed, som kan skabe lugtproblemer. Der findes ikke en færøsk vejledning, så de krav, der stilles, tages ud fra de nordiske lugtvejledninger. Desuden stilles der nogle generelle krav til virksomheder, som ikke har en miljøgodkendelse. Hvis der er lugtproblemer, kan tilsynsmyndigheden stille krav om at få disse problemer løst.

\subsection{Danmark}

I Danmark findes en lugtvejledning, som fastsætter grænseværdier for lugtkoncentrationsbidrag i omgivelserne (12). De oftest forekommende grænseværdier er $5 \mathrm{LE} / \mathrm{m}^{3}$ i boligområder og rekreative områder og 10 $\mathrm{LE} / \mathrm{m}^{3} \mathrm{i}$ industriområder. Den danske enhed $\mathrm{LE} / \mathrm{m}^{3}$ er ikke identisk med den europæiske $\mathrm{ou}_{\mathrm{E}} / \mathrm{m}^{3}$, idet de opnåede lugtresultater $\left(\mathrm{ou}_{\mathrm{E}} / \mathrm{m}^{3}\right)$ fra analysen divideres med en følsomhedsfaktor på typisk 1,3-1,8. De danske enheder i LE/ $\mathrm{m}^{3}$ er således typisk 1,5 gange mindre end de europæiske $\mathrm{ou}_{\mathrm{n}} / \mathrm{m}^{3}$. Følsomhedsfaktoren tager højde for panelisternes følsomhed over for referencestofferne n-butanol og svovlbrinte. Den er oprindeligt 
indført, fordi det blev vurderet, at lugtpanelister reagerede tidligere på lugte end personer i omgivelserne pga. den særlige analysesituation med skærpet koncentration.

Danske miljøgodkendelser for virksomheder med potentiel lugtemission stiller krav om overholdelse af grænseværdierne i omgivelserne. Dokumentationen omfatter prøvetagning og lugtanalyse efterfulgt af en spredningsberegning. Grænseværdierne må kun overskrides i $1 \%$ af tiden i den mest belastede måned ( 99 percentilen).

Hvis virksomheder ikke kan overholde grænseværdierne, skal de iværksætte nødvendige tiltag til at nedbringe påvirkningen. Det kan f.eks. være driftsændringer (reduktion ved kilden), men oftest er det i form af rensningsudstyr, f.eks. skrubbere, aktivt kul eller termisk oxidation.

\section{5 Åland}

Der findes ingen lovgivning, som regulerer lugt i detaljer på Åland. Ifølge Ålands miljøbeskyttelseslov er lugt et eksempel på miljøforurening, som kan medføre negativ miljøpåvirkning, og derfor skal håndteres. /7/

\subsection{Island (8)}

Lugt håndteres fra sag til sag, når miljøtilladelser gives til virksomheder. Der findes ingen officielle retningslinjer for lugtpåvirkning indtil nu. Der kan findes bestemmelser i forordninger, men ikke mange. For virksomheder med intensivt dyreopdræt (f.eks. svinefarm) findes der bestemmelser om afstand til boligområder og fritidshuse. Der findes også i love og regler for affald og luftkvalitet nogle krav om at begrænse lugt.

\subsection{Norge (9)}

I henhold til norsk lov er det forbudt at forurene, og lugt, som giver gener, skal forstås som forurening. Miljødirektoratet har udgivet en vejledning (10) for, hvordan fylkesmennene kan stille krav til lugt. Vejledningen har taget udgangspunkt i de danske retningslinjer, men også erfaringer fra Sverige, Nederland, Storbritannien og Tyskland blev lagt til grund. Der blev derfor med basis i de danske retningslinjer gjort nogle justeringer og tillæg for at adressere de udfordringer, som man så, var gældende. 
Grænseværdien skal overholdes som timemiddel, men der kan stilles specifikke krav til, hvordan udslippet skal beregnes i de tilfælde, hvor der er kortvarige hændelser, som giver lugt.

Vejledningen $ø$ nsker at opfordre den enkelte bedrift/virksomhed til at kommunikere bedst muligt med sine naboer gennem kommunikationsplaner. Uønskede hændelser og situationer udenfor normal drift skal belyses i forhold til lugt gennem en risikovurdering.

Da situationer med diffuse udslip af lugt kan være problematiske, blev der åbnet op for alternative metoder for evaluering af lugtbelastning i sådanne situationer, og der blev givet et intensiv for nabokommunikation, ved at det tillades at bruge nabotilbagemeldinger i evalueringen, forudsat at det er systematiseret i henhold til nogle givne krav.

Forebyggende og beredskabsmæssige tiltag, som er berørt i vejledningen:

- Lugtrisikovurdering.

- Driftsplan, tiltagsplan og internkontrol.

- Lugthåndteringsplan og kommunikationsplan.

Kravstillingen for virksomheder med lugt fra i hovedsagen godt definerbare kilder (såsom punktudslip) er: "Lugtimmisjonen ved omkringliggende boliger, sygehuse, pleieinstitusjoner, fritidsboliger, uddanne institusjoner og barnehager mv. skal ikke overstige (enten 1 eller 2) ou $\mathrm{ou}_{\mathrm{E}} / \mathrm{m}^{3}$ (konsentrasjonen), angitt som maksimal månedlig 99 prosent timefraktil (frekvens og midling)."

Kravstillingen for virksomheder med lugt fra i hovedsagen diffuse udslip er: "Frekvensen af gjenkjennbar plagsom lukt ved omkringliggende boliger, sykehus, pleieinstitusjoner, fritidsboliger, utdanningsinstitusjoner og barnehager mv. skal ikke overstige 1 prosent af timene i en måned (frekvens/hyppighet)."

Frekvensen af genkendelig generende lugt kan dokumenteres ved brug af naboundersøgelser, nabolugtpanel, feltlugtpanel og på samme måde som for punktudslip.

Fylkesmannen står frit for at vurdere strengere krav for den enkelte virksomhed, hvis der er udslip fra flere virksomheder, som påvirker det samme område. 


\section{BAT for nogle industrier}

Som udgangspunkt forudsættes, at de generelle BAT fra kapitel 5.1 for hele FDM sektoren (11) inklusive slagterier og forarbejdning af animalske biprodukter overholdes. Det omfatter blandt andet:

Valg af råvarer, håndtering og opbevaring, god disciplin i forhold til rengøring og oprydning og flere andre punkter, som generelt er væsentlige for at undgå unødige emissioner.

Nedenstående er en kort sammenfatning af det, der overordnet er BAT, både generelt og med udgangspunkt i de enkelte underkapitler i kapitel 8. I den øverste figur er væsentlige punkter anført.

I den efterfølgende tabel 2 er der medtaget en kort oversigt over væsentlige punkter fra de enkelte underkapitler med beskrivelse af konkrete industrier.

Figur 1: Vigtige aspekter ved lugtreduktion
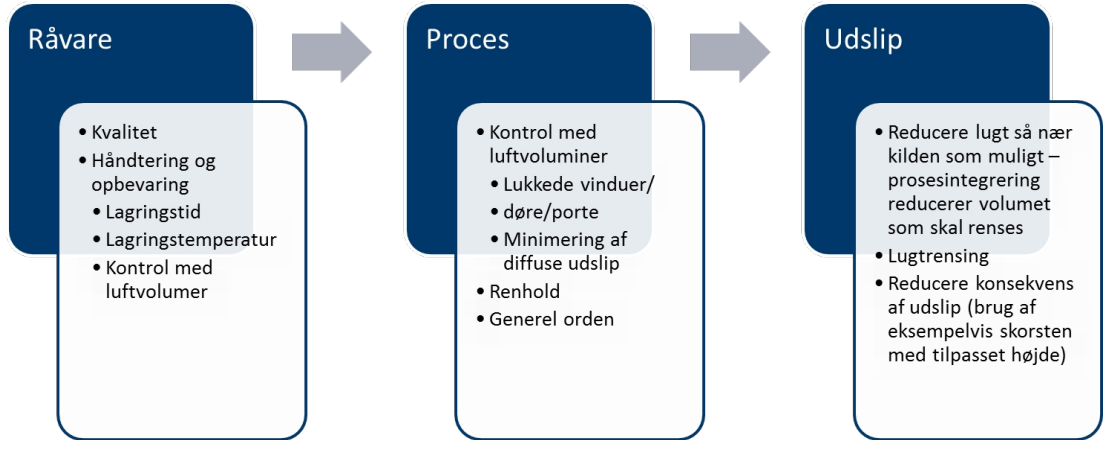
Destruktionsanstalter/

kød-og benmelsfabrikker

Al håndtering og opbevaring af råvarer, produktionsudstyr og færdigvarer skal foregå i aflukkede rum, med rensning af ventilation. Diffuse kilde

Fiskemel og olje

Al håndtering og opbevaring af råvarer, produktionsudstyr og færdigvarer skal foregå i aflukkede rum, med rensning af ventilation. Diffuse kilder reduceres ved brug af sluser eller hur-

tiglukkende porter.

Nedkølet råvare en fordel.

Brug af sugelossere kan give mere lugt til omgivelserne Hvis

der ikke gøres lugtreducerende tiltag.

Tørring af fisk

Industriel produktion indendørs giver $\emptyset$ get mulighed for kontrol af lugt.

Fremstilling af fiskefoder

Fremstilling af andet foder Mindre lugtende råvarer giver nogle flere frihedsgrader sammenlignet med fiskefoder.

Fiskeprodukter bør opbevares nedkølet.

Fremstilling af gær

Produktion af ostepulver
Al rumluft og procesluft skal behandles i lugtreducerende anlæg.

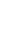

Al rumluft og procesluft skal behandles i lugtreducerende anlæg.

Kontrolleret tilsætning af ozon påvirker processen så produkterne bliver mindre nedbrudt, og det reducerer lugt.

Luft fra råvareindtag, møller og kølere filtreres for partikler.

Luft fra extrudering, lufting og tørring renses.

Ved at erstatte dele af fiskemel med f. eks. ærte-

mel er det mulighed for at opnå rigtig sammensætning, men mindre lugt.

Luft fra råvareindtag, møller og kølere filtreres for partikler.

Luft fra extrudering, luftning og tørring renses.

Luft fra tørring bør renses.

Luft fra ventilation af afløbsrensning renses.

Rumluft ledes over tag.

Luft fra spraytørrer bør vurderes renset.
Håndtere splittede luftstrømmer separat.

Termisk oxidation af ikke-kondenserende procesgasser.

Luft fra haller og rumventilation ledes gennem biofilter og gennem skorsten. Lugt fra håndtering af proteinholdige væsker, herunder også blod: kemisk scrubber.

Alternativ lugtreduktion ved driftstop at termisk oxidation.

Konditionering af luft til lugtreduktionsanlæg for at reducere risiko for dårligere effekt eller tilstopning på grund af fedt.

Procesintegreret lugtreduktion ved fremstilling af fiskemel: Udkondensering/tørring af luft med varmegenvinding, mulig at recirkulere dele af luften. Termisk oxidation på mindre procesluftstrømme.

Koldplasma.

Havvandsscrubber hvor der er mulighed for det.

Ozon.

Procesintegreret lugtreduktion ved fremstilling af fiskefoder: Udkondensering/tørring af luft med varmegenvinding, muligt at recirkulere dele af luften Havvandsscrubber hvor det er egnet.

Biofilter

Høje skorstene (typisk > $100 \mathrm{~m}$ ) kan være tilstrækkelig løsning.

Kemisk scrubber på luft med højt indhold af organiske syrer.

Kemisk scrubber.

Kulfilter.

Kulfilter. 
Røgning

Farmaceutisk industri o fremstilling af kosttilskud

Opløsningsmidler i tanke kan give lugt, og afluftning kan behandles gennem lugtreduktionsanlæg.

Opbevaring af marine råvarer, som for fiskemel og olie.
Røgaroma reducerer lugtpotentialet betydelig med traditionel røgning.
.

Flere røgeovne kan styres så de ikke afgiver mak simal emission på samme tid.

Opløsningsmidler som drives af kan give lugt.

Lugt ofte i forbindelse med varmebehandling og oprensning.
Fjernelse af partikler + kulfilter.

For opløsningsmidler kan genvinding være BAT.

or fermentering kan kondensering eventuelt med efterfølende rensning vær

BAT.

Herudover benyttes generelt termisk oxidation, biofilter eller kulfilter og eventuelt kemisk scrubber. 


\subsection{Destruktionsanstalter/kød- og benmelsfabrikker}

Lugt fra kadavere og i mange tilfælde animalske biprodukter opleves generelt som ubehagelig. Derfor er destruktionsanstalter, hvor der produceres kød-, ben- og blodmel af animalske biprodukter (råvarer) én af de typer virksomhed, som er særligt i fokus, når det omhandler lugt.

Figur 2: Forenklet skitse over lugtkilder fra destruktionsanstalter

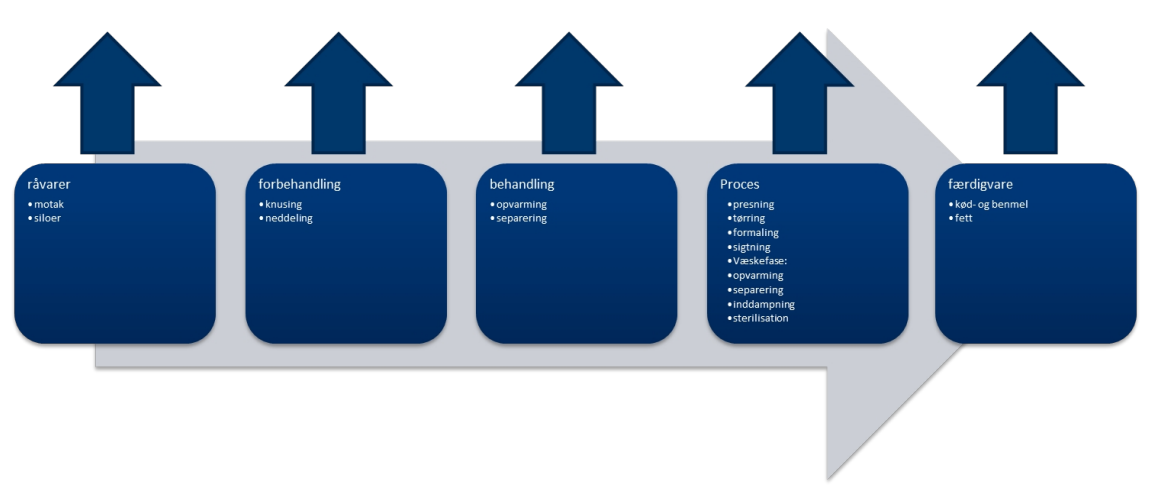

Råvarerne omfatter både selvdøde dyr og biprodukter fra slagterier. De selvdøde dyr er hovedsagelig kreaturer og svin, men herudover er det forudsat, at der også tages imod andre selvdøde dyr, dog ikke fjerkræ, som håndteres på separate anlæg. Kreaturer afleveres typisk separat, da huderne genbruges.

I Danmark er der desuden en særlig periode efterår/vinter, hvor der modtages store mængder mink fra pelsdyrproducenter.

Sammensætningen af råvarer er således meget varierende og samtidig kendetegnet ved ekstremt vekslende kvalitet. Kvaliteten påvirkes af opbevaringstid og temperatur; faktorer, som kan have en væsentlig indflydelse på lugtbilledet. Biprodukter i form af afskær og ben fra slagterier er generelt ferske og rådner ikke så hurtigt, mens kvaliteten af gødning og indvolde hurtigt forringes.

Animalske biprodukter inddeles i tre kategorier efter hvilken risiko, de enkelte produkter udgør for omgivelserne, bl.a. med hensyn til risiko for spredning af smittestoffer og indhold af restkoncentrationer af visse stoffer. Kategori 1-materiale er det, der udgør den største risiko. I Biproduktforordningens (13) artikel 8, 9 og 10 er de tre kategorier af animalske biprodukter listet op. Opdeling i kategorier har afgørende betydning for håndtering og opbevaring af råvarerne. 
I figur 2 er der skitseret et overordnet forløb med lugtkilder. Et typisk forløb for processerne på en destruktionsanstalt består almindeligvis af følgende trin:

- (1) Levering af råvarer.

- (2) Opbevaring i råvaresiloer.

- (3) Knusning.

- (4) Neddeling.

- (5) Opvarmning.

- (6) Separering.

- (7) Presning.

- (8) Tørring.

- (9) Formaling og sigtning.

Ad 1 og 2.

Råvarer leveres enten direkte til siloer eller til slagtehal. I slagtehallen fjernes skind og råvaren knuses og føres til en silo til videre behandling.

Ad 3 og 4.

Råvarerne knuses og neddeles til en størrelse på ca. $20 \mathrm{~mm}$.

Ad 5

De neddelte råvarer opvarmes i en koagulator, hvorefter væske bortdrænes.

Ad 6

I en presse afdrænes yderligere væske, og den efterfølgende behandling er opdelt i en væskefraktion og en tør fraktion. Væskefraktionen fra koagulator og presse, som ledes til videre behandling, går igennem flere yderligere trin:

- Opvarmning.

- Separering.

- Inddampning.

- Sterilisation.

Slutproduktet fra disse trin er fedt. 
Ad 7.

Den tørre fraktion/pressekage tørres sammen med det tørstof, der er resultatet af separationsprocessen af væskefraktionen.

\section{Ad 8.}

Det tørrede produkt formales og sigtes til slutproduktet, som er kød- og benmel.

Børster håndteres for sig, men på virksomhedens område, og luften fra behandling af disse behandles sammen med anden luft fra produktionen. I Danmark behandles blod på en separat fabrik.

I forbindelse med alle operationer/processer er der en potentiel lugt, som kan give gener i omgivelserne.

Det er generelt vigtigt at være opmærksom på, at det er al lugt, som har sammenhæng med virksomheden, der af omkringboende vil blive registreret, ikke kun den, der kommer ud af skorstenene. Derfor er der en række generelle forholdsregler, som skal tages for at begrænse påvirkningen af omgivelserne mest muligt.

Det er meget væsentligt, at arealer og lastbiler, som transporterer råvarer m.m., rengøres og, at eventuelt spild på køre- og friarealer med det samme fjernes. Hvis der ikke fokuseres herpå, kan det give anledning til gener, uanset hvor meget der i øvrigt gennemføres af lugtreducerende foranstaltninger. Det bør derfor sikres, at en række forhold er i fokus for at undgå unødig lugt fra diffuse kilder. Det drejer sig om:

- Krav til transporter, lukkede vogne/containere, eventuelt med køling.

- Rengøring af lastvogne efter tømning.

- Rengøring af udearealer.

- Ingen råvarer må henstå udendørs.

For selve processerne skal der tages hensyn til:

- Al håndtering og opbevaring af råvarer, produktionsudstyr og færdigvarer skal foregå i aflukkede rum.

- Der skal være undertryk i rummene, og luften skal ledes til et behandlingsanlæg. Der må ikke forekomme åbne vinduer, døre eller porte, hvor luften kan ledes til det fri. Dog skal det naturligvis være muligt at komme ind og ud af bygninger, ligesom råvarer skal kunne leveres på en hensigtsmæssig måde. 
- Levering af råvarer skal foregå enten via en sluse eller med hurtigt lukkende porte, så mulighed for emission af lugt minimeres.

For at minimere lugtpåvirkning af virksomhedens omgivelser omfatter den bedst tilgængelige teknik, at al rumluft og procesluft skal behandles i lugtreducerende anlæg og efterfølgende ledes til det fri via et eller flere afkast med en tilstrækkelig højde til at undgå unødig påvirkning af omkringboende.

For at opnå dette og sikre den optimale lugtreduktion og samtidig minimere driftsomkostninger er det umiddelbart fordelagtigt at splitte luftstrømme op i ikke kondenserende gasser og anden lugtbelastet luft. Disse to luftstrømme håndteres separat.

Det er i Danmark den foretrukne teknologi, at de ikke kondenserende gasser, hvilket som udgangspunkt vil sige al luft fra processer, ledes til et termisk oxidationsanlæg og efterfølgende ledes til det fri via et afkast med en passende højde.

Den mindre lugtbelastede luft fra slagtehal, råvarehal og rumventilation i øvrigt ledes efter befugtning til et biofilter. Biofilteret skal være overdækket, og den rensede luft ledes til det fri via et afkast med en passende højde. Biofilteret har typisk en størrelse, så belastningen med luft er ca. $100 \mathrm{~m}^{3} / \mathrm{h} / \mathrm{m}^{2}$ filteroverflade, og med en højde af filtermaterialet på ca. $1 \mathrm{~m}$.

Reduktion af lugt fra håndtering af proteinholdige væsker, herunder blod foregår i Danmark på et separat anlæg. Her benyttes en kemisk skrubber til at behandle de mest lugtbelastede luftstrømme, som udgør ca. $40 \%$ af den samlede luftstrøm. Sammen med rumventilation ledes den rensede luft til det fri via en skorsten.

Der skal tages højde for, at det termiske oxidationsanlæg til behandling af ikke kondenserbare gasser i perioder kan være ude af drift. Driftsstop kan være planlagte eller spontane. Da produktionen ikke blot kan lukkes ned spontant, er det vigtigt, at luften ledes til anden behandling, inden den ledes til det fri, da urenset luft vil blive registreret af de omkringboende, også selv om den emitteres via et højt afkast. Typisk kobles luften til biofilteret. Herved opnås en væsentlig reduktion, men den ekstra belastning af biofilteret kan have betydning for filterets effektivitet, også efter at den mest belastede luft igen kan behandles på det termiske oxidationsanlæg.

Der vil typisk være meget høje krav til lugtreduktionsanlæggene på en destruktionsanstalt. For biofilterets vedkommende fordi der er tale om en betydelig luftmængde på typisk mere end $200.000 \mathrm{~m}^{3} / \mathrm{h}$. For det termiske oxidationsanlæg er kravene ligeledes $h ø j e$, men her primært fordi 
der er tale om meget høje lugtkoncentrationer, der skal reduceres. Kravene afhænger af højden af de efterfølgende afkast.

Også på anlæg i Sverige benyttes termisk oxidation til lugtreduktion. Her er der dog valgt en anden fremgangsmåde, benævnt Biomal -konceptet i forbindelse med håndering af råvarerne.

Konceptet går grundlæggende ud på at reducere de energikrævende processer til fremstilling af fedt og mel af råvarerne. Råvarerne knuses og neddeles, hvorefter de forbrændes sammen med for eksempel flis, tørv eller affald. En række af de lugtintensive processer benyttes derfor ikke.

I Norge er der en række anlæg til destruktion af slagteriaffald m.m., og der er valgt forskellige lugtreduktionsløsninger, tilpasset de lokale forhold:

- Ved en lokation benyttes totrins kemisk skrubber og biofilter.

- Ved en anden benyttes termisk oxidation til punktafsug og kulfilter til behandling af rumluft.

- Ved en tredje lokation er der i dag en ettrins vandskrubber og et biofilter.

- Ved en fjerde lokation overvejes det at ændre fra vandskrubber til to trins kemisk skrubber.

Den generelle erfaring er, at biofilter fungerer godt når det er stort nok dimensioneret. Opbygningen af biofilter vil fremover være et systematisk opbygget filter med barkflis.

Det er generelt vigtigt med forbehandling af luften inden reduktionsanlæggene. Dette er for at fjerne partikler/aerosoler af fortrinsvis fedt. Herved undgås tilstopning mv. af reduktionsanlæggene. Fjernelsen kan eventuelt ske ved filterkassetter.

En del luft kan afbrændes i kedler til aflastning af biofilteret. Det er dog i denne sammenhæng væsentligt at være opmærksom på mulig korrosion, og denne reduktionsmetode er fravalgt i Danmark.

I forbindelse med produktionen fremkommer spildevand, som i sig selv kan være årsag til lugtgener. Det lykkes dog ved hensigtsmæssig placering af spildevandsrenseanlæg og omhyggelig drift at undgå unødig påvirkning af omkringboende, selv om anlæggene er åbne.

\section{Reduktionsanlæg}

Al rumventilation fra produktion, råvarehal og slagtehal føres til biofilter og efterfølgende til skorsten.

Punktudsug fra processer med ikke kondenserende gasser og med højt lugtindhold behandles ved termisk oxidation efter forbehandling. 
Luften til de respektive anlæg skal konditioneres for at undgå forringelse af effektiviteten eller tilstopning på grund af fedt.

Et økonomisk overslag baseres typisk på et biofilter i størrelsesordenen $2.000 \mathrm{~m}^{2}$ med en filterbelastning på ca. $100 \mathrm{~m}^{3} / \mathrm{h} / \mathrm{m}^{2}$ filteroverflade og et termisk anlæg til behandling af ca. $25.000 \mathrm{~m}^{3} / \mathrm{h}$. Hertil kommer passende skorstene, som typisk kan blive op til $90 \mathrm{~m}$. En skorsten i denne størrelse med vil typisk beløbe sig til ca. 2.000.000 DKK.

Etablering af et overdækket biofilter til behandling af ca. $200.000 \mathrm{~m}^{3} / \mathrm{h}$ vil beløbe sig til ca. 10.000.000 DKK. Driftsomkostninger er fortrinsvis til ventilatorer og vanding. Hertil kommer vedligehold og forbrug af mandetimer til løbende kontrol. Filtermaterialet består i Danmark typisk af Leca ${ }^{\circledR}$. Der kan regnes med mere end 5 år mellem hver udskiftning af materiale. Hvis andet materiale, såsom barkflis benyttes, må der forventes en kortere tid mellem udskiftninger.

Der skal i overvejelserne om hvilket filtermateriale, der skal benyttes, tages hensyn til bortskaffelse af det brugte materiale. Leca® kan typisk returneres til producenten/leverandøren, hvor det genanvendes i fremstilling af nye produkter.

Et anlæg til termisk forbrænding af $25.000 \mathrm{~m}^{3} / \mathrm{h}$ koster ca. DKK 5.000.000. Driftsomkostninger omfatter fortrinsvis ca. $5.500 \mathrm{~m}^{3}$ naturgas pr. uge + vedligehold + mandetimer. På grund af den meget korrosive luft er kravene til vedligehold meget store.

De er meget vigtigt, at lugtreduktionsanlæggene kontrolleres og vedligeholdes jævnligt og trimmes for at fungere optimalt.

Blandt andet kanalføringer, ventilatorer og fundamenter kommer oveni de skitserede overslagspriser.

\subsection{Fiskemel og olie}

Et typisk produktionsforløb fra en fabrik til fremstilling af fiskemel og fiskeolie består kort beskrevet af følgende trin:

- (1) Levering af råvarer/losning.

- (2) Kogning.

- (3) Presning.

- (4) Dekantering.

- (5) Centrifugering.

- (6) Inddampning.

- (7) Tørring. 
- (8) Køling.

- (9) Formaling.

- (10) Pakning/lagring.

Ad 1.

Råvarer, der tilføres virksomhederne, kan enten være fra industrifiskeri, biprodukter fra fiskebearbejdningsindustrien eller kombinationer heraf. Råvarerne enten suges ind for eksempel direkte fra en fiskekutter til råvaresiloer, optages med pumpe eller grab eller leveres direkte i åbne siloer.

Ad 2.

Råvarerne koges. Herved steriliseres de, og kogningen gør det lettere efterfølgende at separere olie og tørstof.

Ad 3.

Ved presning separeres meget af væsken, og det pressede materiale føres til tørrere. Væsken føres til decantere, hvor partikler fjernes og føres tilbage til tørreren og blandes med tørstof fra presningen. Væsken føres til separatorer hvor olien tages fra.

Ad 5.

Vandfasen fra separatorerne ledes til inddampere hvor den opkoncentreres og efterfølgende ledes til pressekagen i løbet af tørreprocessen.

Ad 7.

I tørrerne fjernes vand.

Ad 8-10.

Fiskemelet køles, formales og pakkes. 
Figur 3: Forenklet skitse over lugtkilder fra fremstilling af fiskemel og -olje

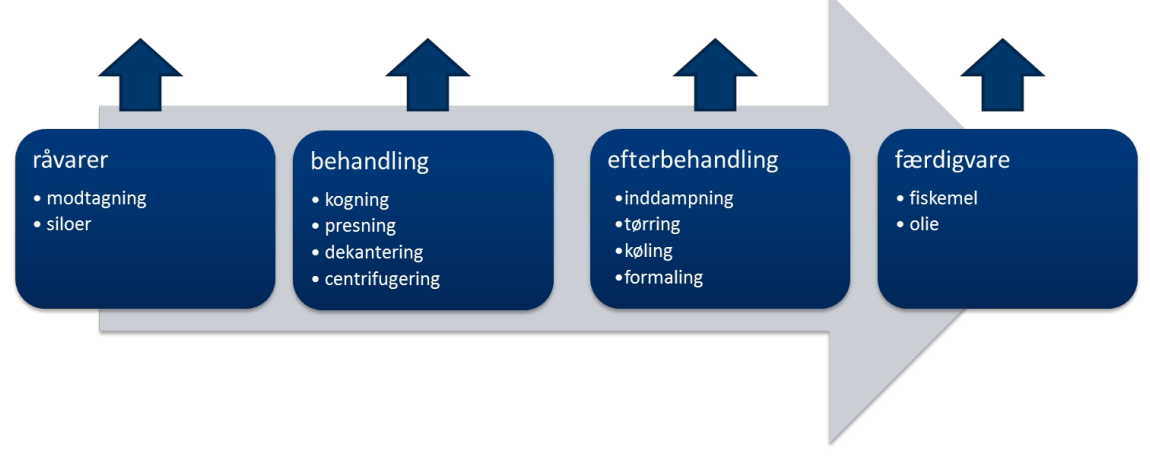

Allerede i forbindelse med losning er det vigtigt at fokusere på lugt. Hvis der anvendes sugelossere kan råvarerne komme til at afgive væsentlig lugt, da de både udsættes for mekanisk påvirkning og varmes op.

Generelt skal samme forholdsregler overholdes som for destruktionsanstalter, så diffuse lugtemissioner i videst muligt omfang begrænses. Kvaliteten af råvarerne har gennemgående stor betydning for lugtafgivelsen. Kvaliteten er generelt blevet forbedret i løbet af de senere år, og den afregning, der er for råvarerne er et incitament til at levere dem friske. Råvarerne opbevares på køl umiddelbart efter fangst eller afskær og bearbejdes hurtigt efter, at de er leveret til fabrikkerne.

Procesluft fra virksomheden behandles typisk ved forbrænding. Lugtreduktionen foregår ofte som en kombination af termisk oxidation i et eller flere regenerative anlæg, som genbruger varmen internt, forbrænding i virksomhedens egne kedler og emission til det fri via passende afkast.

Anvendelse af kedelanlægget til lugtreduktion er dog begrænset, da kapaciteten ofte kun vil være tilstrækkelig til at behandle en delluftstrøm.

På nogle virksomheder i Danmark og på Færøerne benyttes kedlerne til lugtreduktion efter forudgående vask af procesluft i havvandsskrubbere (14).

På Island er der det særlige forhold, at der kun er få konventionelle kedelanlæg, da brændslerne er erstattet med elektricitet (14).

Hvor der er mulighed for det i Norge og Island benyttes havvandsskrubbere, som er velegnede til behandling af lugtemissionerne.

Også aktivt kul og kemiske skrubbere kan være aktuelle. Der skal dog foretages nøje økonomiske overvejelse, da både kul og skrubbere er dyre til store luftstrømme, men til gengæld effektive til luftstrømme med høje 
koncentrationer. I Island er der tidligere også gjort brug af kemiske skrubbere, fortrinsvis, når råvarekvaliteten var ringe, og der var behov for supplerende lugtreduktion.

Ligeledes anvendes for eksempel i Norge kold plasma teknologi til reduktion af nogle delluftstrømme. Der er ikke kendskab til anvendelse af biofiltre, formentlig primært på grund af pladsmangel eller længere perioder med varierende eller ingen drift.

Det forudsættes, at partikelindholdet i den luft, der skal behandles, er nedbragt til et acceptabelt niveau i forhold til reduktionsanlæggene. Endvidere skal luften eventuelt konditioneres, så også temperatur og fugtindhold er optimal i forhold til den videre behandling.

Generelt kan mange rensningsteknologier benyttes, og den optimale løsning er individuel. Dog vil der under alle omstændigheder være behov for, at alle luftstrømme (behandlede såvel som ubehandlede) ledes til det fri via afkast med en passende højde.

\section{Procesintegreret lugtreduktion}

Ved fremstilling af fiskemel kan kondensering af fugtig varm luft fra f.eks. tørrere have en gunstig effekt på lugtemissionen. Ved kondenseringen fjernes en del af de vandopløselige lugtstoffer. Dette har tre væsentlige konsekvenser:

- (1) Lugtemissionen reduceres.

- (2) Den luft, der eventuelt efterfølgende skal håndteres i lugtreducerende anlæg, er mindre belastet og forekommer i en lidt mindre luftstrøm.

- (3) Luften er koldere, og dermed reduceres risikoen for kondensering i kanaler og i reduktionsanlægget.

Hertil kommer en eventuel mulighed for recirkulering af luften og i gunstige tilfælde genbrug af den kondenserede væske.

Hvorvidt det er en økonomisk fordel afhænger blandt andet af behovet for at behandle eller genbruge kondensatet, og hvorledes køling kan foretages. Hvis ikke kondensatet kan benyttes, kan der desuden være udfordringer i forhold til bortskaffelse af det.

Netop økonomien har bevirket, at der til dato kun anvendes kondensering få steder. 


\subsection{Tørring af fisk}

I flere af de Nordiske lande er der en lang tradition for at tørre fisk. Formålet er historisk at konservere fisken.

Tørring af fisk er almindeligvis forgået ved at anbringe den klargjorte fisk i stativer udendørs, hvor der kan foregå en naturlig tørring. I industriel målestok foretages der en tørring i tørrekamre, så hele processen kan gennemføres på kortere tid og bedre kontrolleret.

Figur 4: Forenklet skitse over lugt fra industriel tørring af fisk/fiskehoveder

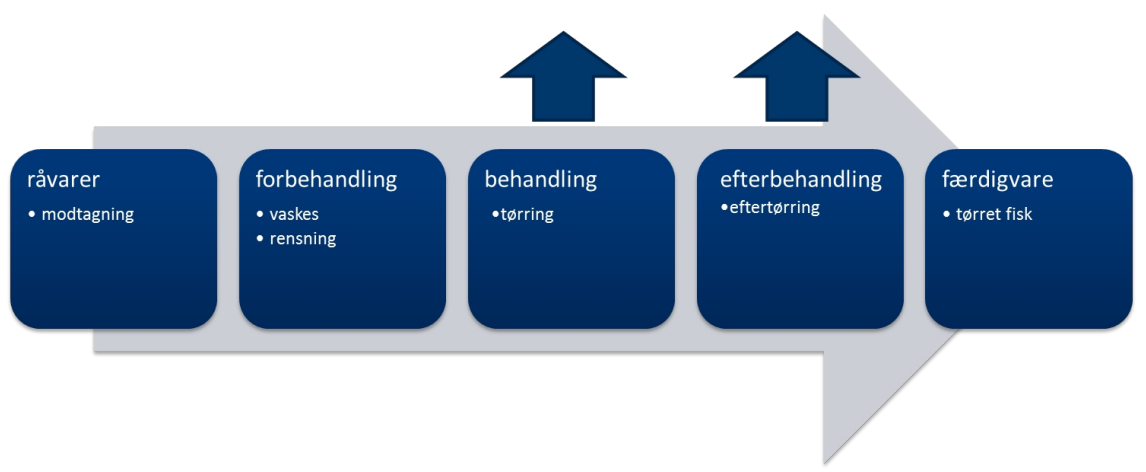

De indkomne råvarer vaskes/renses, hvorefter de placeres i for eksempel egnede bakker. Bakkerne anbringes i et tørrekammer, hvortil der indblæses varmluft. Efter en passende tid tages produkterne ud af tørreskabene og anbringes i et mellemlager til eftertørring. De henstår her, til de har nået den ønskede grad af tørhed. Herfra flyttes de til færdigvarelager og videre til pakning og forsendelse.

Det er i flere lande blevet den mest anvendte teknologi at reducere lugt fra processerne til omgivelserne ved kontrolleret tilsætning af ozon. Ozon tilsættes vaskevandet og det tilsættes ligeledes i tørreskabene. Endelig tilsættes i nogle tilfælde også ozon til afkast fra eftertørring og færdigvarer.

Udover at have en effekt på den emitterede lugt har ozonen den virkning, at det begrænser nedbrydning/ forrådnelse af kødet. Dette i sig selv vil reducere lugtemissionen.

I forbindelse med dosering og anvendelse af ozon skal der være opmærksomhed omkring arbejdsmiljø/indeklima og den emission, der vil kunne forekomme til omgivelserne. 


\subsection{Fremstilling af foder}

\section{Fiskefoder}

Et typisk forløb for foderfremstilling omfatter følgende procestrin, hvorfra der i varierende grad er mulighed for emission af lugtstoffer:

- (1) Levering af råvarer.

- (2) Formaling.

- (3) Extrudering.

- (4) Tørring.

- (5) Coating.

- (6) Køling.

- (7) Pakning.

Ad 1.

De indleverede råvarer opbevares i siloer.

Ad 2.

Kombinationer af råvarer blandes og formales.

Ad 3.

I extruderen opvarmes blandingen, og materialet ledes gennem en matrice, så der formes piller af den ønskede størrelse.

Ad 4-6.

Pillerne tørres, hvorefter de coates og nedkøles

Ad 7.

Det færdige produkt pakkes.

Ud over luft fra disse procestrin er der lugtholdig luft fra aspiration/transportluft. Denne luft omfatter blandt andet afsugning fra lukkede transportsystemer. 
Figur 5: Forenklet skitse over lugtkilder ved fremstilling af foder

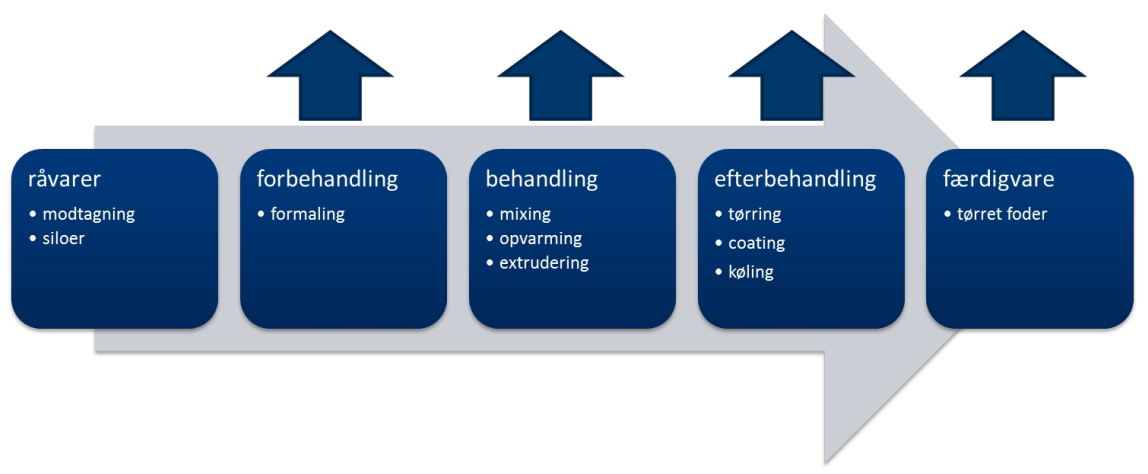

Bedst tilgængelige teknologi varierer fra anlæg til anlæg, men er primært baseret på lokale forhold.

Hvor der er mulighed for det, vil BAT være at benytte havvandsskrubbere kombineret med et passende afkast.

I havvandsskrubberne er det nødvendigt med rengøring, da der kan forekomme biofilm som forøger trykfaldet over skrubberen. Det er samtidig vigtigt at evt. partikelfiltre vedligeholdes, så der ikke opstår tilstopning.

Typisk vælges at føre udslip fra råvareindtag, møller(formaling) og kølere til det fri via separate eller fælles afkast efter forudgående filtrering for partikler.

I lande/områder, hvor det ikke er muligt at rense med havvand, er den anbefalede teknik biofiltre til de belastede luftstrømme fra extrudering, aspiration og tørring. Der kan være tale om enten åbne filtre eller overdækkede filtre, hvor den rensede luft ledes til det fri via et afkast med en passende højde.

Det vil i de fleste tilfælde ikke være muligt at opnå en tilstrækkelig fortynding af den samlede luft fra produktionen via høje afkast til at overholde gældende lugtgrænser og derved undgå uønsket lugtpåvirkning.

Da en væsentlig del at lugten fra produktionen stammer fra fiskemel, er det til en vis grad muligt at reducere lugtemissionen ved at substituere noget af dette med for eksempel ærtemel. En forudsætning for denne substitution er naturligvis, at det er muligt i forhold til den sammensætning, foderet skal have, og at det er økonomisk forsvarligt.

Den samlede luftmængde fra en fiskefoderfabrik vil typisk ligge i størrelsesordenen $150.000-200.000 \mathrm{~m}^{3} / \mathrm{h}$.

Hvis det vælges at behandle al luften i et biofilter, vil omkostningerne typisk blive i samme størrelsesorden, som for destruktionsanstalter. 
Havvandsskrubbere vil typisk koste i størrelsesordenen DKK 5.000.000 for håndtering af ca. $100.000 \mathrm{~m}^{3} / \mathrm{h}$ luft, hvor der dog også skal investeres i kanaler, ventilatorer og eventuel partikelfjernelse. Herudover skal der investeres i en eventuel lang ledning til at skaffe det nødvendige havvand og en ledning til bortskaffelse af havvandet efter brug i skrubberen.

Der er ikke i Finland (16) stillet krav om eller vurderet et behov for at foretage reduktion af lugten fra de anlæg, der findes til fremstilling af fiskefoder. Behovet vurderes for den enkelte situation.

\subsubsection{Andet foder}

\section{Fremstilling af tørfoder til kvæg svin og fjerkræ}

Anden tørfoder fremstilles i det væsentlige på samme måde som fiskefoder. Dog er ingredienserne i fremstillingen almindeligvis mindre lugtende. Lugt opstår typisk i forbindelse med sterilisering ved opvarmning med damp.

Den almindelige og tilstrækkelige bedste teknologi til begrænsning af lugt i omgivelserne fra denne produktion er etablering af høje afkast (skorstene). Ofte er denne type produktionsanlæg placeret i omgivelser med stor afstand til naboer, på landet eller i havneområder, men erfaringsmæssigt har det vist sig, at også virksomheder, der er placeret i eller i nærheden af bymæssig bebyggelse kan nøjes med en skorstensløsning. Dog vil kravet til skorstenshøjden for at kunne overholde et acceptabelt lugtniveau i virksomhedens omgivelser kunne give anledning til skorstenshøjder som overstiger $100 \mathrm{~m}$, og det kan på grund af andre forhold være problematisk eller ikke lovligt.

I Finland har det vist sig, at der ikke er uønsket lugt fra produktion af dyrefoder, og der er derfor ikke etableret lugtreducerende foranstaltninger.

\section{Foder til kæledyr}

Foder til kæledyr fremstilles som udgangspunkt ligesom foder til fiskeopdræt, kvæg og svin. Der er dog en del af produktionen, hvor der fremstilles vådt foder.

Lugtemissionen fra produktion af vådt foder er generelt lavere end fra tørt foder. Ved den våde proces sker der ingen opvarmning af råvarerne før de er i lukkede beholdere (dåser). Først her udsættes produkterne for høj temperatur ved autoklavering så det sikres, at alle levende organismer, som ellers kunne forårsage sygdom, destrueres. 


\section{Hunde- og kattefoder}

En hunde- og kattefoder fabrik i Sverige anvender en lang række forskellige animalske og vegetabilske råvarer til at producere en stor variation af tørfoder og vådfoder (i dåser) i forskellige smagsvarianter, så valg af foder bl.a. kan tilgodese dyrenes art, størrelse, aktivitetsniveau og sundhedstilstand.

Animalske råvarer er kød fra okse, kalv, lam, vildt, kylling, kalkun, laks og anden fisk, som opbevares nedkølet, for at sikre holdbarhed og kvalitet frem til anvendelse i produktionen.

Vegetabilske råvarer er forskellige kornprodukter og grøntsager, og der anvendes tillige forskellige tilsætningsstoffer til at forbedre produkternes smag og næringsværdi.

Ved produktion af tørfoder blandes alle ingredienser til en produkttype i batchproduktioner, hvor det æltes og forarbejdes og opvarmes med damp, hvorefter det under tryk kortvarigt opvarmes kraftigt, så det steriliseres. Herefter presses massen gennem et hul-skive, og skæres af i passende stykker, som giver tørfoderet størrelse, som derefter tørres i en stor ovn til det ønskede lave vandindhold, hvorved der også opnås en sprød konsistens. Efter afkøling fyldes produktet i poser eller bokse og pakkes til færdigvarelageret.

Produktionen af vådfoder svarer stort set til tørfoder bortset fra, at efter æltning og forarbejdning, fyldes massen i foliebakker, som lukkes hermetisk og varmebehandles i en autoklave. Efter afkøling påsættes etiketter, og det pakkes i kasser til færdigvarelageret.

Virksomheden ligge i landlige omgivelser i udkanten af en by, så der er nogen afstand til de få nærmeste naboer. Det er kun ved begrænsede vindretninger, at der potentielt kan blæse lugt ind over byen, hvor der bor mange mennesker, mens der er meget spredt beboelse i de andre retninger.

Den primære kilde til lugtemission er afkastet fra tørringen af tørfoder. Der har tidligere været klager over denne lugt fra tørreanlægget, så for nogle år siden blev der derfor etableret en højere skorsten på ca. 25 meter til dette afkast.

For år tilbage har der formentlig været lugtgener fra oplag af råvarer, hvor specielt fiskeprodukter hurtigt afgiver lugt, men med den nuværende opbevaring på køl, samt bedre styring af leverancerne, så det passer med forbruget og tiden på råvarelageret bliver kort, er risikoen for lugt væsentligt reduceret.

Der er andre eksempler på, at luften fra produktion af kæledyrsfoder på andre virksomheder renses i biofiltre, bioskrubbere og ved termisk oxidation. 


\subsection{Fremstilling af gær}

Fabrikken, der er fra 1973, ligger i et industriområde i udkanten af byen. De nærmeste naboer er derfor andre industrivirksomheder, mens der er 3-400 meter til den nærmeste bolig, som er i landdistriktet, med spredte boliger og landbrug i området.

Virksomheden producerer gær, som hovedsageligt er specielle gærtyper og gærekstrakt samt bagegær og vingær. Virksomheden er blandt andet verdens største producent af gær til vinfremstilling. Tidligere var der også en produktion af ethanol, men den er for nyligt blevet nedlagt (i 2013) (17).

\subsubsection{Produktionen af gær}

Virksomheden producerer gær ud fra 50-70 forskellige gærstammer. Produktionen af en gærstamme starter med ganske få milligram gær fra en renkultur, der opformeres i 4 eller 5 trin. Disse trin kaldes fedbatch fermenteringer, hvor steril næring baseret på melasse og næringssalte samt vitaminer kontinuerligt sættes til fermentoren.

De 4-5 opformeringstrin tager 7 dage og i løbet af de 7 dage bliver 1 milligram gær til 30-35 tons gær tørstof, som ville kunne pakkes til 2 millioner 50 gr. pakker. Gærproduktion er en skrøbelig proces, da temperaturen kun må svinge ganske lidt. Derfor overvåges produktionsudstyret i døgndrift i et højtautomatiseret kontrolrum. Udover at sikre at gæren har den rette temperatur, udtages der også løbende prøver for at følge gærens vækst og sikre den rette kvalitet.

Gæren høstes fra fermentorerne ved hjælp af specielle centrifuger. Ved centrifugeringen fremkommer der en gærfløde med ca. 20 \% gærtørstof. Gærfløden er den råvare, der bruges videre i de forskellige produktioner, hvor gæren eksempelvis opkoncentreres på filtre og pakkes i 50 gr. pakninger til detailsalg eller tørres ved lav temperatur, således at man får en aktivt tørgær til vinproduktion eller som ingrediens i dyrefoder.

Den største del af gæren bliver videreforarbejdet til specialprodukter såsom gærekstrakt, der eksempelvis bruges som smagsgiver i krydderier.

\subsubsection{Lugtemission fra gærproduktion}

Virksomheden har fra starten produceret både gær og ethanol. Der er emission af lugt fra en række afkast fra delprocesser i produktionen og fra bassiner til rensning af spildevandet fra produktionen. Selvom produktionen i 
en vis udstrækning kan lugtes i omgivelserne, har der i årenes løb kun været relativt få klager. Det kan skyldes en kombination af, at lugten ikke er så voldsom, og at der er relativt langt til de få boliger, der er tættest på.

De største kilder til lugtemission kommer fra rensningsanlæggets bufferbassin med råspildevand samt fra afkastet ved spraytørring af selenholdige gærspecialiteter. Derudover er der mindre emissioner ved fyldning af diverse lagertanke samt fra fermentorernes luftafkast.

Der har i mange år været fokus på at nedbringe lugtemissionen, og kilderne til lugtemission er blevet kortlagt i flere omgange. Bedre styring af processerne samt fokus på at undgå spild og fejl har reduceret lugtemissionen fra specielt spildevandsrensningen, men for nogle af de væsentligste kilder er det ikke muligt at reducere lugtemissionen på den måde.

Nogle af de væsentligste kilder er i løbet af de seneste år blevet reduceret eller fjernet ved procesomlægning: Det er specielt nedlæggelse produktionen af ethanol produktionen og tørring af selenberiget gær, der har medført en væsentlig reduktion af lugtemissionen og dermed potentialet for lugtgener i omgivelserne. Lugtemissionen fra tørringen af selenberiget gær, har tidligere givet anledning til klager over lugtgener, og produktet tørres stadig i mindre omfang. Hovedparten tørres nu på fabrikker i England og Estland. Tørreluften fra tørring af gær renses i en skrubber, hvor bl.a. organiske syrer absorberes effektivt i basisk vand, som løbende $\mathrm{pH}$ regulereres med base.

Langt den største emission af lugt kommer i dag fra anlægget til rensnings af spildevandet fra produktionen, i særdeleshed fra udligningsbassinet med råspildevand, mens lugten fra beluftningsbassinet er lav og svarer til baggrundslugten i omgivelserne og derfor ikke giver anledning til gener.

\subsection{Lugtemission fra mejerier}

Det er bredt accepteret, at mejerier ikke har udfordringer på lugtområdet, og der er derfor ikke nogle foretrukne eller anbefalede lugtreduktionsmetoder (18).

Lugt kan dog forekomme ved specielle produktioner på særlige anlæg. 


\subsection{Beskrivelse af produktionen af ostepulver}

Virksomheden er én af verdens største producenter af ostepulvere til en række andre industrier. Virksomhedens pulvere bruges som ingrediens i forskellige produkter til snacks, kiks, færdigretter mm. Pulverne virker både som smagsgiver og som smagsforstærker og er særligt kvalificerede ved at kunne leveres med ensartet smag og sammensætning. Flere af kundernes produkter kan godt laves med almindelig ost, men pga. smagsvariationen i oste vil fremstillingsprocessen kunne variere fra gang til gang. Med et ostepulver kan man anvende den samme mængde hver gang og opnå den samme smag.

Figur 6: Forenklet skitse over lugtkilder ved fremstilling af ostepulver

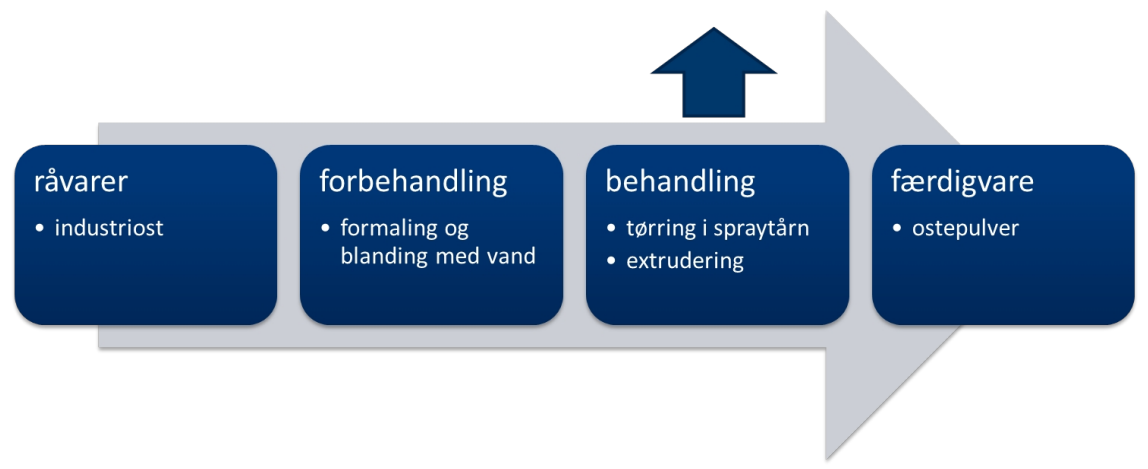

De primære råvarer ost kommer fra mejerier og er kendetegnet som industriost. Fremstillingen af ostepulver ligner meget processen ved fremstilling af smelteoste. Ostene oparbejdes til et feed ved, at de bliver hakket og blandet med vand. Hallen, hvor feedet fremstilles, ventileres ved almindelig rumventilation og udledes over tag. Lugtemissionen herfra er ikke vurderet at udgøre et problem, og der er derfor ingen luftrensning.

I spraytårnet forstøves feedet, og partikler falder ned gennem en varm luftstrøm, og vandet fordamper. Ved fordampningen af vand ved den forholdsvis høje temperatur sker der også fordampning af lugtstoffer, der har et væsentligt damptryk ved den aktuelle temperatur. Disse lugtstoffer emitteres gennem skorsten over tag. Pga. den højere temperatur og den totale fordampning af vand frigives så mange lugtstoffer, at lugtemissionen kan være høj. Emissionen varierer fra produkt til produkt. Et produkt med Danbo kan give anledning til lugtkoncentrationer på op mod ca. $20.000 \mathrm{ou}_{\mathrm{E}} / \mathrm{m}^{3}$. Andre produkter med milde oste (f.eks. flødeost eller Cheddar) kan give anledning til lugtemissioner ned til ca. $2.500 \mathrm{ou}_{\mathrm{E}} / \mathrm{m}^{3}$. På virksomheden emitteres luften i ca. 25 meters højde, men det er ikke 
tilstrækkeligt til at sikre mod væsentlig påvirkning i naboområdet og dermed lugtgener.

Tørreluften indeholder flere stoffer, der er bl.a. fundet carboxylsyrer, svovlforbindelser og kvælstofholdige forbindelser (ammoniak og indol en sekundær amin) samt carbonylforbindelser. En rensningsløsning skal målrettes mod at kunne klare de specifikke kemiske forbindelser. Samtidig skal løsningen tage hensyn til virksomhedens fysiske forhold. De aktuelle stoffer kan for en dels vedkommende opløses i vand og dermed fjernes i en skrubber. Flere af stofferne kan også adsorberes i et kulfilter. Begge disse løsninger vurderes at være teknisk gode.

Virksomhedens muligheder for at etablere skrubber eller kulfilter som totalrensning er begrænset, bl.a. pga. store luftmængder og behovet for at føre kanaler fra taget ned til jorden. Det er derfor valgt at indlede et samarbejde med et firma, som leverer en oxidationsløsning med meget stærke oxidationsradikaler. En del af de observerede stoffer kan oxideres, og leverandørens antagelse er, at de oxiderbare stoffer (f.eks. aminer) lugter mere end de dannede reaktionsprodukter (f.eks. carboxylsyrer). Selvom antagelsen er korrekt, vil reaktionsprodukterne have en vis lugt (f.eks. vil butansyre - smørsyre - lugte kraftigt). Der er således begrænsninger i reduktionspotentialet, som er meget afhængigt af stofsammensætningen i luften. Om oxidationsløsningen er BAT afhænger af, om den opnåede rensning er tilstrækkelig. Under alle omstændigheder har denne løsning tilgodeset virksomhedens begrænsninger. Hvis ikke rensningen er tilstrækkelig, kan det være nødvendigt at supplere med andre løsninger til f.eks. produktionen af særlige produkter, der emitterer vanskeligt oxiderbare stoffer.

Efter tørretårnet føres pulveret til pakning i variable emballager, f.eks. $20 \mathrm{~kg}$ sække. I pakkehallen er produktet kølet af, og fordampning af lugtstoffer er minimal. Der er således intet problem med lugtgener pga. ventilationsluften fra pakkehallen.

Der er på virksomheden identificeret én væsentlig lugtkilde - spraytørringen. Andre lugtkilder er ikke større end, at rumventilation over tag i en passende højde sikrer både medarbejdere og naboer. Emissionen fra spraytørringen søges behandlet med oxidation, men det kan blive aktuelt med supplerende behandling. 


\subsection{Røgning}

Røgning er oprindeligt en konserveringsmetode, der er baseret på

- at der sker der en udtørring og deraf følgende hæmning af levnedsmiddelødelæggende processer

- at koldrøgning giver en kemisk virkning både på overfladen og $\mathrm{i}$ dybden ved nogle af de i røgen forekommende forbindelser

- at der ved varmrøgning sker der en pasteurisering med drab af vegetative celler.

I dag anvendes røgning hovedsageligt som smagsgiver, og produktet ændrer også farve og konsistens. Konservering udføres typisk ved andre metoder.

Den anvendte røg fremstilles ved forbrænding/pyrolyse af træ. Derved dannes flere hundrede stoffer, hvoraf kan nævnes eddikesyre, phenolforbindelser, andre flygtige og ikke-flygtige syrer, metanol, formaldehyd og nogle højere aldehyder, ketoner og høj molekylære hydrocarboner. Der skelnes mellem (19)

- koldrøgning - ved temperaturer omkring $15-22^{\circ} \mathrm{C}$. Det anvendes, hvor produktets ingredienser ikke må f.eks. smelte (spæk i spegepølse). Ved koldrøgning trænger røgen dybt ind i varen og giver en meget lang holdbarhed. Koldrøgning anvendes f.eks. til spegepølse, spegeskinker, leverpølse, spæk og fisk

- halvvarm røgning - ved temperaturer omkring 30-50 ${ }^{\circ} \mathrm{C}$. Det giver produktet mindre røgsmag og er mindre konserverende end koldrøgning. Halvvarm røgning anvendes til fremstilling af produkter som f.eks. bacon, hamburgerryg, bayonneskinke, røget filet, rullepølse og forskellige pølsetyper

- varmrøgning - ved temperaturer omkring 50-90 ${ }^{\circ} \mathrm{C}$. Varmrøgning anvendes i dag udelukkende for smag og udseendes skyld. Den høje temperatur bevirker, at proteinerne vil koagulere (stivne), og produktet får derfor et varmebehandlet udseende. Produkter som wienerpølser, cocktailpølser, frokost- og grillpølser og fisk bliver varmrøget.

Rent fysisk er røgen nærmest en aerosol, dvs. en blanding af luft og små vanddråbe i størrelse omkring $0,1 \mu \mathrm{m}$, samt enkelte faste partikler som 
sod. Røgens hovedbestanddele, kvalitativt såvel som kvantitativt, findes opløst i de små væskedråber.

Da betydningen af røgning er ændret fra konservering til smagsgiver er røgaroma blevet et interessant alternativ. Røgaroma eller røgkondensat er fællesbenævnelsen for en gruppe af produkter, som enten kan være vandbaserede, vandopløselige, olieopløselige eller være et tørt pulver. Alle produkterne er standardiserede og fremstilles ved en ufuldstændig forbrænding af træflis i en stor røggenerator, der omdanner træflisen til aske og røg. Røgen kondenseres, og asken separeres fra. Ved en efterbehandling separeres tjærefasen med de kræftfremkaldende stoffer fra. I forhold til traditionel røgning opnås adskillige fordele: Ingen brandfare, et sundere arbejdsmiljø, et renere røgeprodukt og et minimalt udslip (herunder lugtemission) til naturen. Desuden er produkterne standardiserede, hvilket ikke er tilfældet for traditionel røg.

Røgaroma kan påføres ved enten at blande dem direkte i en fars, ved at dyppe produktet i opløsningen, overbruse produktet eller ved at bruge en røggenerator, der skaber en røgsky, som reagerer med kødets eller fiskeproduktets overflade på samme måde som traditionel røg.

Om røgaroma kan anvendes som en total erstatning af traditionel røgning er betinget af forbrugernes holdning. Der er indikationer på, at anvendelse af røgaroma i nogle forbrugeres opfattelse er lig med "noget kunstigt". Derfor foretrækker mange stadig traditionelt røgede produkter. Der er dog forskelle i opfattelsen i Danmark og Sverige, idet svenskerne i langt højere grad opfatter røgaroma som en accepteret produktionsmetode (20)(19).

I relation til denne rapports formål er det væsentligt, at emissionen af lugt fra røgerier reduceres betydeligt i forhold til traditionel røgning se afsnit 4.8.1.

Røgeindustrien omfatter et stort antal små røgerier med små røgeovne. Det er f.eks. detailforretninger og mobile udsalgssteder og slagtere og slagterafdelingerne i supermarkeder. Derudover er der et antal større industrielle røgerier på større fødevareproducerende virksomheder, f.eks. slagterier.

\subsubsection{Anvendelse af røgaroma}

En stor dansk virksomhed, som producerer en lang række røgede produkter, fik et behov for at reducere lugtpåvirkningen af omgivelserne. Man indledte derfor forsøg med flydende røg, som blev påført produkterne i et "røgkammer", hvor den flydende røg blev sprøjtet på produkterne. Til 
sammenligning blev der udført traditionel røgning af tilsvarende produkter. Lugtmålinger viste, at anvendelse af traditionel røg gav 18 gange større lugtemission i forhold til anvendelse af røgaroma. Der var således en meget betydelig effekt af den ændrede metode.

Det viste sig desværre, at kunderne ikke tog godt imod de nye produkter, men klagede over en ændret, dårligere smag. Virksomheden valgte derfor at gå væk fra metoden og installerede i stedet forbrænding af røgen fra processerne, som således er BAT for netop denne virksomhed.

En virksomhed producerer kyllingepølser med røgsmag ved tilsætning af flydende røg til pølsefarsen. Virksomheden oplyser (21), at sådanne produkter ikke har samme smag som traditionelt røgede produkter, og hele produktionen sælges til eksport, bl.a. fordi danske forbrugere $ø$ nsker en helt anden smag. Virksomheden producerer ikke traditionelt røgede produkter. Brug af flydende røg er derfor ikke her et alternativ til traditionel røgning og rensning af luften.

\subsubsection{Røgning af pølser}

Et større dansk slagteri fremstiller et bredt udvalg af f.eks. grillpølser. Røgeriet omfatter et større antal røge- og tørreovne, hvorfra røgen gruppevis går til fællesafkast. For bedst muligt at kunne vurdere mulighederne for reduktion af lugtpåvirkning af omgivelserne er der foretaget en lang række lugtbestemmelser under forskellige driftsformer. Målingerne viser, at røgning giver væsentligt større lugtemission end tørring. For nogle produkter var den gennemsnitlige lugtemission ca. $90.000 \mathrm{ou}_{\mathrm{E}} / \mathrm{s}$ for $\mathrm{r} ø \mathrm{~g}$ og ca. $21.000 \mathrm{ou}_{\mathrm{E}} / \mathrm{s}$ for tørring.

Spredningsberegninger viste, at ved drift af samtlige ovne samtidig ville der være en overskridelse af gældende grænseværdier ved naboerne. Virksomheden havde derfor behov for lugtreduktion og arbejdede med forskellige muligheder. Man forsøgte bl.a. med adsorption på aktivt kul, hvilket reducerede lugten med op til $95 \%$. Pga. et højt indhold af partikler og fedt i røgen stoppede kulfilteret imidlertid hurtigt til, og denne løsning blev derfor opgivet. Aktivt kul vurderes at kunne være BAT til at fjerne lugtstoffer fra røgning, hvis den nødvendige fjernelse af partikulær forurening etableres før kulfilteret.

Virksomheden forsøgte også at anvende UV-genereret ozon. Denne teknik havde ingen effekt, hvilket blev dokumenteret ved flere målinger. Virksomheden søgte i stedet myndigheden om lov til at søge påvirkningen begrænset gennem bedre spredning af lugten gennem høje afkast og sam- 
tidig bedre produktionsstyring, så samtidige lugtemissioner fra flere afkast blev undgået. Myndigheden accepterede denne mulighed, og BAT for denne virksomhed er således:

- Stram produktionsstyring.

- Fortynding og spredning gennem høje afkast.

\subsection{Farmaceutisk industri og fremstilling af kosttilskud}

Produktion af lægemidler/farmaceutiske præparater kan bestå i meget forskellige processer. Eksempelvis kan produktion af kalktabletter forventes at give lidt lugt, mens produktionsprocesser baseret på fermentering i farmaceutisk sammenhæng, som i næringsmiddelsammenhæng kan give et betydelig potentiale for lugt.

En groft skitseret farmaceutisk produktionsproces indebærer modtagning af indsatsvarer, bestående af råvarer, opløsningsmidler og lignende. For en stor producent vil opløsningsmidlerne være lagret i tanke med naturlig trykudjævning. Dette giver rum for tab af opløsningsmidler ved at luften inde i tanken mættes med opløsningsmiddel, og denne kan frigives til det fri ved fyldning af tanken, eller dersom tanken gennemstrømmes med luft. Hvis syntese er del af produktionen, vil opløsningsmidler benyttet i syntesen ofte drives af som et led i processen. Hvis dette ledes til det fri, vil dette være et potentielt lugtudslip. Opløsningsmidler og andet procesvand vil også kunne have lugt, og lugt vil kunne frigives ved lagring i tanke, behandling og afledning til afløb. Det er også rapporteret, at bebyggelse som er påkoblet det samme kommunale afløbsledningsnet, kan opleve lugt på grund af rester af eller reaktioner med produkter eller opløsningsmidler i afløb fra farmaceutisk produktionslinje. Ved oprensning er lugtpotentialet normalt mindre, men opløsningsmidler med et indhold af reaktanter og produkter er også her en mulig kilde. Det er ikke usædvanligt at afløb fra oprensning renses med tanke på genvinding af både reaktanter og produkter, og dette kan forventes også at være en mulig kilde til lugt Dosering, emballering og lagring af emballerede produkter afgiver normalt lidt lugt De som har gennemført tiltag for at reducere opløsningsmiddeludslip til luft, har gerne valgt en løsning med termisk oxidation. 
Figur 7: Grovskitse af produktionslinje. Pilene viser, hvor det mest sandsynlig emitteres lugt

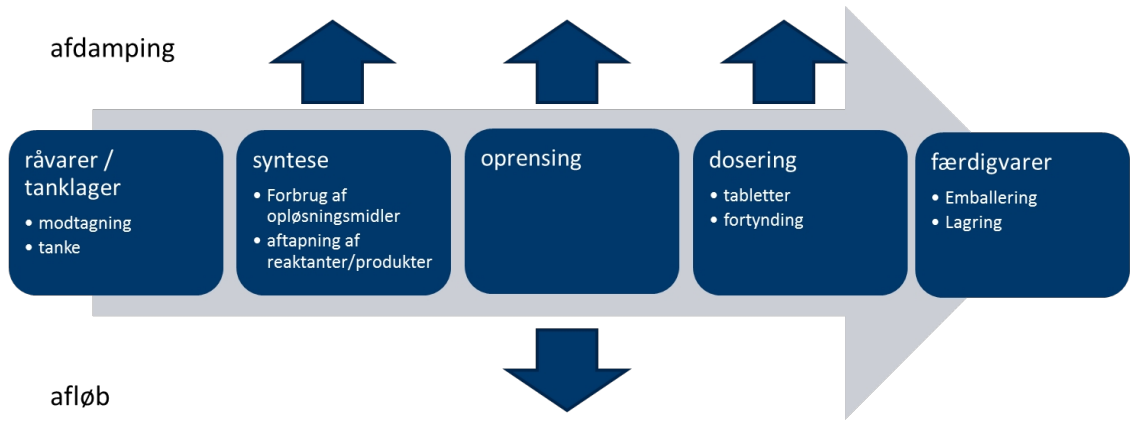

Note: Vertikale piler indikerer procestrin med forventet lugtafgivelse.

Hvis vi udvider begrebet farmaceutiske producenter til at omfatte mulige indsatstoffer i bl.a. kosttilskud og udvikling af bl.a. omega-3 deriverede lægemidler, finder vi en række virksomheder, som producerer baseret på marine råvarer. Produktionen er i stor grad fokuseret omkring fiskeolier og omega-3, men også kitin og andre stoffer.

Det er ikke rapporteret, at produktion af alginat baseret på tang og tare (søgræs) har skabt lugtproblemer, men produktion af f.eks. kitin, som baseres på rejeskal, kan have nogen udfordringer på lugt fra råstoffet. Det er derfor ikke usædvanligt at tanke, procestanke og afluftning går til eksempelvis et vasketårn (havvandscrubber) og afkast over tag.

Figur 8: Forenklet skitse af forædling af fiskeolie

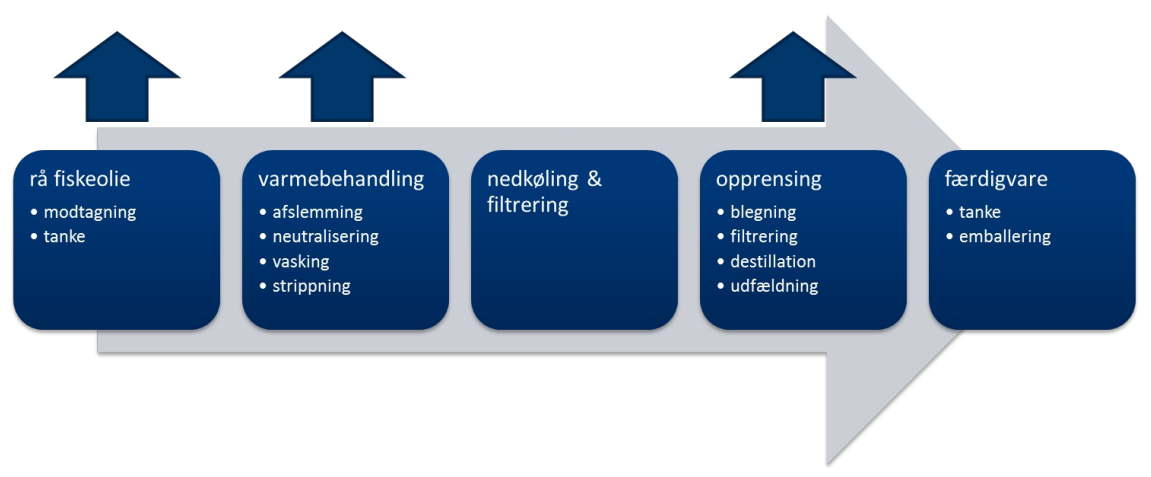

Note: Vertikale pile indikerer procestrin med forventet lugtafgivelse. 
Råstof til fiskeolie kan have mange kvaliteter, og også her kan der være meget lugt fra det enkelte råstof, mens selve produktionen kan være ganske lukket, og de processer som er lugtstærke behøver ikke at medføre en stor volumenmængde luft, som skal renses. Der er alligevel betydelige lugtpotentialer. Rå fiskeolie modtages som oftest med skib, og gerne i lukkede systemer. Lagertankene kan være lugtkilder, specielt på grund af luft, som fortrænges ved påfyldning. Derefter er der en forbehandling af olien, hvor den varmes op, afslemmes, neutraliseres, vaskes og strippes. Varmebehandlingen og strippingen er lugtkilder. Olien køles derefter ned før videre oprensning, som gerne gøres med kombination af opvarmning, blegning, filtrering, destillation og udfældning. Ofte er det at fjerne smag og lugt på slutproduktet også et mål med dette trin, og det må forventes, at der er potentiale for, at der afgives en del lugt Da en del af processen foretages i opvarmet fase, er der en betydelig risiko for diffuse udslip fra processen. Det kan forventes, at det største lugtpotentiale er knyttet til de varme faser.

Inden for den farmaceutiske industri er der en stor variation i den anvendte løsning til lugtreduktion.

Reduktionsløsningerne er individuelle og baseret på økonomi og lokale muligheder/begrænsninger, og der kan ikke siges noget generelt om den bedste teknologi.

Typisk vil der fortrinsvis være tale om anvendelse af kulfiltre, biologiske filtre og termisk oxidation, i kombination med en skorsten. Reduktion ved kondensation og kemiske skrubbere finder også anvendelse, hvor det er mere hensigtsmæssigt.

Der er således flere muligheder for at bestemme den økonomisk mest fordelagtige metode eller kombinationer heraf. 



\section{Referencer}

(1) Air quality - Determination of odour concentration by dynamic olfactometry

(2) Karina Ødegaard: Status for håndtering af lukt i noen europeiske land, Statens forurensningstilsyn, 2009.

(3) Tillståndsvillkor och luktförekomster vid biogasanläggningar i Sverige (Permit conditions and odour occurences on Swedish biogas plants).

(4) Sten-Åke Barr, Henrik Bjurström, Markus Olofsgård, Mårten Arbrandt, Ulrika Follin, Mattias Wesslau: Utvärdering och rekommendationer för reningsteknik afseende på lukt vid anläggningar för återvinning af organiskt affall och kommunala reningsverk. Waste Refinery, 2013.

(5) Tuula Kajolinna, Research Scientist, VTT Technical Research Centre of Finland Ltd., P.O.Box 1000, FI-02044 VTT, Phone +358 405624379.

(6) Lena Ziskason, umhvørvisstovan, vernd, telefon: +298 2343 41, email: lenaz@us.fo

(7) Susanne Särs, Miljöskyddsinspektör, Ålands miljö- och hälsoskyddsmyndighet, Norragatan 17, AX-22 100 Mariehamn, Åland.

(8) Sigurður Ingason, Umhverfisstofnun, Environment Agency of Iceland, Suðurlandsbraut 24, 108 Reykjafík, Iceland.

(9) Karina Ødegård, Senioringeniør / senior consultant, Molab as, Tlf / phone: (+47) 92434 858, E-post / email: karina.odegard@molab.no

(10) Veileder fra Klima- og Forurensningsdirektoratet: Regulering af luktutslipp I tillatelser etter forurensningsloven.

(11) IPPC Reference Document on Best Afailable Techniques in the Food Drink and Milk Industries.

(12) Vejledning fra Miljøstyrelsen nr. 4 1985. Begrænsning af lugtgener fra virksomheder

(13) Miljø- og fødevareministeriet: Biproduktforordningen nr. 1069/2009

(14) Danmark og Færøerne.

(15) Informationer fra personlig kontakt til Hedinn.

(16) Personlig kommunikation med Raisio.

(17) Rune Engel-Hansen, De Danske Gærfabrikker, Bredstrupvej 33, 8500 Grenaa. Tlf.: +4587582400.

(18) Vedtaget på TWG møde I Sevilla oktober 2014. I forbindelse med kick off på revision af BREF for FDM. http://www.backstugan.com/17686409

(19) Artikel i Jyllandsposten: Forbrugere foretrækker røgvarer - trods kræftrisiko: http://jyllands-posten.dk/indland/ECE3324006/ Forbrugere+foretr\%C3\%A6kker+r\%C3\%B8gede+varer++trods+kr\%C3\%A6ftrisiko/?page $=4$

(20) Personlig samtale med fabrikschef, Søren Bay, HKSCAN. 



\section{Ordliste}

Tabel 1: Ordliste til rapport om lugt

\begin{tabular}{llll} 
Dansk & Finsk & Norsk & Svensk \\
Formål & Tavoite & Formål & Syfte \\
Lugt & Haju & Lukt & Lukt \\
Lugtgene & Hajuhaitta & Luktulempe & Luktstörning \\
Måling & Mittaus & Måling & Mätning \\
Lugtrensning & Hajunpoisto & Luktrensning & Luktreduktion \\
Levnedsmiddel & Elintarvike & Næringsmiddel & Livsmedel \\
Begreb & Käsite & Begrep & Begrepp \\
Oversigt & Katsaus & Oversikt & Översikt \\
Forbrænding & Poltto & Forbrenning & Förbränning \\
Skrubber & Pesuri & Vasker/skrubber & Skrubber \\
Køling & Jäähdytys & Kjøling & Kylning \\
Aktivt kul & Aktiivihiili & Aktivt kull & Aktivt kol \\
Kød- og benmel & Liha- ja luujauho & Kjøtt- og benmel & Kött- och benmjöl \\
Fiskemel & Kalajauho & Fiskemel & Fiskmjöl \\
Olie & Öljy & Olje & Olja \\
Foder & Rehu & Fôr & Foder \\
Gær & Hiiva & Gjær & Jäst \\
Mejeri & Meijeri & Meieri & Mejeri \\
Ostepulver & Juustojauhe & Ostepulver & Ostpulver \\
Røgning & Savustus & Røyking & Rökning \\
Kosttilskud & Ravintolisä & Kosttilskudd & Kosttillskott \\
Havvandsscrubber & Merivesipesuri & Sjøvannsvasker & Saltvattensskrubber \\
\hline & & & \\
\hline & & & \\
& & & \\
\hline
\end{tabular}





\section{Sammenfatning engelsk}

Some industries in the Nordic countries have odorous emissions. Whether the odour that is emitted from the industry is responsible for odour in the surroundings and that this is perceived as a nuisance is based on a number of different conditions. In a society where the industry is placed close to residential and recreational areas, the risk of odour nuisance has grown and odour is therefore now an environmental parameter. The industry in the Nordic countries is very varied and different from country to country with regard to production the size of the industry and conditions such as quality and type of raw materials, operating periods, topography and geographical placement. These conditions have a great impact on how odour is perceived and the general impact on the surroundings.

In the table below, there is a short summary of the techniques used to reduce the odour from different industries.

For odour, an acceptable solution is to reduce the impact on the surroundings by emission through a suitable stack. However, in many cases, this is not enough and then other abatement systems should be applied.

Tabel 1: Short summary

\begin{tabular}{|c|c|c|c|}
\hline & Storage/handling & Process & Exhaust \\
\hline Rendering & $\begin{array}{l}\text { All handling and storage of } \\
\text { raw materials, equipment } \\
\text { and products shall take place } \\
\text { in closed rooms, with clean- } \\
\text { ing of the exhaust air. Fast } \\
\text { closing gates and/or locks } \\
\text { shall be used }\end{array}$ & $\begin{array}{l}\text { All air streams shall be } \\
\text { treated in odour abate- } \\
\text { ment systems before they } \\
\text { are emitted to the sur- } \\
\text { rounding air }\end{array}$ & $\begin{array}{l}\text { Divided air streams should be treated } \\
\text { separately. } \\
\text { Thermal oxidation of noncondensing } \\
\text { process gasses. } \\
\text { Ventilated air from production premises } \\
\text { through a biofilter and to the surround- } \\
\text { ings via a stack with appropriate height. } \\
\text { In case of malfunction of the thermal } \\
\text { oxidation, the air to this unit shall be } \\
\text { led through the biofilter. } \\
\text { Odour from handling of protein con- } \\
\text { taining liquids such as blood are typi- } \\
\text { cally treated in a chemical scrubber }\end{array}$ \\
\hline $\begin{array}{l}\text { Fish meal and } \\
\text { oil }\end{array}$ & $\begin{array}{l}\text { All handling and storage of } \\
\text { raw materials, equipment } \\
\text { and products shall take place } \\
\text { in closed ventilated rooms, } \\
\text { with cleaning of the exhaust } \\
\text { air. Fast closing gates and/or } \\
\text { locks shall be used }\end{array}$ & $\begin{array}{l}\text { All air streams shall be } \\
\text { treated in odour abate- } \\
\text { ment systems before they } \\
\text { are emitted to the sur- } \\
\text { rounding air }\end{array}$ & $\begin{array}{l}\text { Process integrated odour reduction: } \\
\text { Condensation of drying of air with heat } \\
\text { recovery and a possibility to recirculate } \\
\text { some of the air. } \\
\text { Thermal oxidation on small odorous } \\
\text { process air streams. } \\
\text { Seawater scrubbers where acceptable } \\
\text { and possible. } \\
\text { Cold plasma }\end{array}$ \\
\hline
\end{tabular}




\begin{tabular}{|c|c|c|c|}
\hline & Storage/handling & Process & Exhaust \\
\hline Drying of fish & $\begin{array}{l}\text { Industrial production indoor } \\
\text { gives better possibility to } \\
\text { control the odour }\end{array}$ & $\begin{array}{l}\text { Controlled addition of } \\
\text { ozone affects the process } \\
\text { so that the products are } \\
\text { less destroyed and it re- } \\
\text { duces odour }\end{array}$ & Ozone \\
\hline \multirow[t]{3}{*}{ Fish feed } & $\begin{array}{l}\text { All handling and storage of } \\
\text { raw materials, equipment } \\
\text { and products shall take place } \\
\text { in closed rooms. }\end{array}$ & $\begin{array}{l}\text { Air from intake grinding } \\
\text { and coolers shall be fil- } \\
\text { trated from particles. } \\
\text { Air from extruder and dry- } \\
\text { ing should be treated. }\end{array}$ & $\begin{array}{l}\text { Process integrated odour reduction: } \\
\text { Condensation of drying of air with heat } \\
\text { recovery and a possibility to recirculate } \\
\text { some of the air. }\end{array}$ \\
\hline & & $\begin{array}{l}\text { By substitution of parts of } \\
\text { the fishmeal with other } \\
\text { suitable ingredients is pos- }\end{array}$ & $\begin{array}{l}\text { Seawater scrubbers where acceptable } \\
\text { and possible }\end{array}$ \\
\hline & & $\begin{array}{l}\text { sible to obtain the right } \\
\text { composition with less po- } \\
\text { tential odour emission. }\end{array}$ & Biofilter. \\
\hline Feed & $\begin{array}{l}\text { Raw material especially with } \\
\text { fish products shall be kept } \\
\text { cool and in closed rooms. }\end{array}$ & $\begin{array}{l}\text { Air from intake grinding } \\
\text { and coolers shall be fil- } \\
\text { trated from particles. } \\
\text { Air from extruder and dry- } \\
\text { ing should be treated in } \\
\text { suitable odour abatement } \\
\text { systems. }\end{array}$ & $\begin{array}{l}\text { High stacks (typically > } 100 \mathrm{~m} \text { ) can be a } \\
\text { sufficient solution. }\end{array}$ \\
\hline Yeast & & $\begin{array}{l}\text { Air from drying and air } \\
\text { from ventilation of } \\
\text { wastewater treatment } \\
\text { shall be treated in odour } \\
\text { abatement systems. }\end{array}$ & $\begin{array}{l}\text { Chemical scrubber to treat air with a } \\
\text { high content of organic acids. }\end{array}$ \\
\hline Chease powder & & $\begin{array}{l}\text { Odour in the air from } \\
\text { spray drier should be re- } \\
\text { duced }\end{array}$ & $\begin{array}{l}\text { Chemical scrubber. } \\
\text { Charcoal filter }\end{array}$ \\
\hline $\begin{array}{l}\text { Pharmaceutical } \\
\text { industry }\end{array}$ & $\begin{array}{l}\text { Odour emission form sol- } \\
\text { vents in storage tanks can be } \\
\text { handled by odour abatement } \\
\text { equipment } \\
\text { Marine raw materials } \\
\text { should be handled like in the } \\
\text { fish meal industry. }\end{array}$ & $\begin{array}{l}\text { Odour often from heating } \\
\text { and cleaning up. }\end{array}$ & $\begin{array}{l}\text { For solvents recovery can be BAT } \\
\text { For fermentation condensation and } \\
\text { eventual treatment in odour abatement } \\
\text { system can be BAT. } \\
\text { Often thermal oxidation is used as } \\
\text { odour abatement system but a number } \\
\text { of other techniques are also used. }\end{array}$ \\
\hline
\end{tabular}




\section{BAT for lugtreduktion inden for levnedsmiddel- og fodervirksomheder}

Der er i Norden forskellige retningslinjer for hvilke lugtniveauer, der bør være omgivelserne af virksomhederne. Generelt er der ingen krav til etablering af lugtreduktionsanlæg, hvis niveauet kan opnås gennem fortynding via skorstene. Hvor skorstensløsning ikke er tilstrækkelig eller lokale forhold sætter grænser for højden kan det dog være nødvendigt med etablering af lugtreducerende anlæg.

I rapporten er resultaterne af disse overvejelse for nogle brancher i Norden beskrevet. FORCE Technology og Molab AS har udarbejdet denne rapport, som beskriver de teknologier til lugtreduktion, som benyttes inden for nogle brancher i Norden.

Projektet er finansieret af Nordisk Ministerråds arbejdsgrupppe for Holdbar Konsumtion og Produktion (HKP), vis undergruppe for BAT spørgsmål har styret projektet.

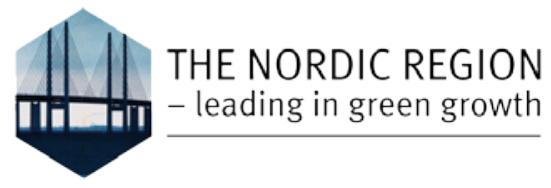

TemaNord 2016:516

ISBN 978-92-893-4514-9 (PRINT)

ISBN 978-92-893-4516-3 (PDF)

ISBN 978-92-893-4515-6 (EPUB)

ISSN 0908-6692

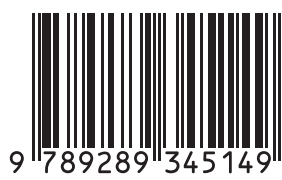

